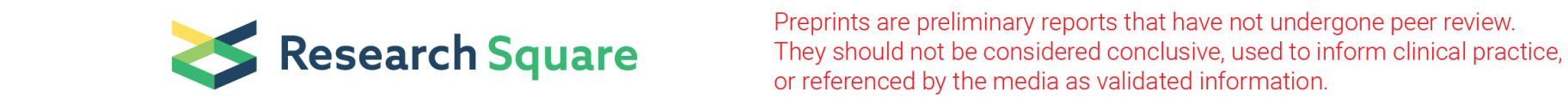

\title{
Model Study of a Single Pile With Varied Configuration in Sand
}

Mohamed A. Sakr

Tanta University Faculty of Engineering

Waseim R. Azzam

Tanta University Faculty of Engineering

Hatem K. Kassim ( $D$ PG_90983@f-eng.tanta.edu.eg )

Tanta University Faculty of Engineering

\section{Research Article}

Keywords:

Posted Date: July 30th, 2021

DOI: https://doi.org/10.21203/rs.3.rs-765451/v1

License: (1) This work is licensed under a Creative Commons Attribution 4.0 International License. Read Full License 


\section{Abstract}

In this experimental work, the influence of pile cross-section with varied configurations on the axial compression load capacity of a single pile and related settlement in sand are investigated. The influence of relative sand density $\left(D_{r}\right)$, the pile length to diameter $(L / D)$ ratios and the pile installation techniques are presented. A testing program comprising seven model steel piles with varied shapes of $20 \mathrm{~mm}$ width/diameter was conducted. The tests are performed on model piles with the pile length to diameter ratios of 10 and 30 installed in the three cases of sand modeling as loose, medium dense and dense sand. Results indicated that, the rectangular pile is the optimization cross-sectional under the same pile geometry and soil conditions. Also, the increase of the relative sand density has a significant influence on the ultimate compression pile load. Furthermore, the ultimate axial loads of flexible piles in the case of loose sand using the nondisplacement method were found to be increased by $119 \%, 114 \%, 143 \%, 82 \% 139 \%, 89 \%$ and $100 \%$ comparing with the ultimate axial loads of rigid piles for the seven models of closed-ended pipe, open-ended pipe, conical base pipe, square closed-ended, square openended, tapered and rectangular piles respectively. While, these percentages were found to be increased by $(49 \%, 37 \%, 26 \%, 78 \%, 35 \%, 71 \%$ and $91 \%)$ and $(77 \%, 50 \%, 13 \%, 116 \%, 61 \%, 89 \%$ and $85 \%)$ in the cases of medium dense and dense sand respectively. The results also indicated that, piles installed in sand using jacking technique have more resistance compared with piles installed in sand using nondisplacement technique.

\section{Introduction}

Piles are slender structural elements and extremely recommended as a load transferring system under superstructures with a great performance. Structural loads are transferred to deeper stable layers via pile foundations [40]. Piles are commonly used to support offshore platforms, marine structures, tower foundations, bridge abutments and superstructures. Pile load capacity and related settlement corresponding to the applied loads play a key role in the design and construction of pile foundations [48]. Considerable studies (theoretical, experimental and semi-experimental methods) were performed in the past to evaluate the pile load capacity and in sand. These methods can be categorized into three sections: 1 st section, estimating the pile base capacity $[11,37,41,51,55] ; 2$ nd section, estimating the pile shaft capacity $[11,18,27,30,35,36,37,38,44,53,55]$, finally, the effect of critical depth $[41,46,54,59]$. Most design methods idealize the pile-soil system to a certain extent; hence, the influence of various additional factors affecting the pile load capacity in sand should be investigated [28]. There are main factors affecting pile load capacity can be classified by dividing into four sections: soil characteristics, pile characteristics, methods of pile installation technique, and the nature of loading [29, 39]. The process of pile designs and studies of the mechanism of interactions between piles and sand up to the 20th period continuous depending generally on relations with the observed resistance during the pile installation technique and loading process [28].

On the other hand, piles can be classified into two categories depending on the nature of their placement as displacement and nondisplacement piles. Driven piles are displacement piles, due to these piles during installing technique are produced laterally movement and densification to soil surrounding pile walls [12]. Driven pile technique includes the use of hammers to provide impacts that are necessary to install piles into soil layers. These pile techniques create noise, vibrations, air pollution and may cause damage to nearby structures and facilities. Therefore, these techniques are environmentally unfriendly techniques [60]. In response, alternative construction techniques for piles have been developed. These developments have been driven by a desire either to increase the performance of piles and to minimize the environmental impact of its construction. Presently, a method for installing piles that includes the use of hydraulic jack to drive piles into soil layers that is identified as jacked pile technique. Jacked pile technique is becoming more widely accepted and a viable alternative installation technique method for displacement piles. Also, jacked pile technique has commonly acknowledged advantages as a quick installation process and high pile capacity without noise, vibration and air pollution [6, 31, 58]. While, De Beer [13] indicated that, driven piles have about three times of the base resistance comparing with bored and cast-in-situ piles. In order to support sensitive structures for settlements and transfer heavy vertical loads and a large uniform loads from superstructures, there is a need to more advanced approaches or techniques in relation to the pile load capacity. Therefore, more investigations were performed to find a pile-modification techniques and to study the mechanism of interactions between piles and sand. So, there is a need for a selection of some investigations for example, the load capacity of open-ended pipe piles is highly affected by the soil-plugging [20]. The influence of soil-plugging for openended pipe piles is greatly influenced by the pile driving conditions [9], pile geometry properties [17], and soil conditions [43]. The pile shape is affected by the shaft resistance, with for example the family of tapered piles. Manandhar et al. [33] concluded that, a small increase in tapering degree of the pile affects significantly on a higher skin friction comparing with conventional straight piles at different sand relative densities. Other investigations studied the factors that directly affect the pile load capacity as pile geometry $[16,21,22,26$, 49], pile material [10], pile installation technique methods $[1,2,15]$ and soil conditions $[14,45]$. Due to install piles into a thick strata and difficult driving conditions, steel conical driving shoes are the preferred end closure for open-ended pipe piles. The conical point distributes the shock load equally around the pile perimeter and not causing added stresses on one section of the pile. Typically, the conical point has 
a sixty-degree configuration that is preferred over flatter angles [25]. Furthermore, there are several alternative predictive approaches are available to exactly estimate the pile load capacity and related settlement for examples, Shahin [50] provided state-of-the-art review of some selected Artificial Intelligence (Al) techniques and their applications in pile foundations using cast in place real model of pile load tests by many factors and also discussed the strength and limitations of the selected Al techniques. Additionally, Jebura et al. [24] were developed a novel approach of multi-layered artificial neural networks (ANN) based on the Levenberg-Marquardt approach (LM) by conducting several experimental studies using three categories of steel open-ended pipe, steel closed-ended pipe and square concrete piles as tested models.

Full-scale field tests are commonly expensive and hard to perform. Pervious literatures were limited in studying the influence of pile crosssection on the axial load capacity of a single pile. In addition, the cross-section of pile has a great effect on the design procedures of foundation. Therefore, this research aimed to investigate the geotechnical behavior of a single pile in sand at different pile configuration. In this experimental work, the influence of relative sand density $\left(D_{r}\right)$, the pile length to diameter ratio $(L / D)$, and the pile installation techniques are discussed.

\section{Experimental Work}

\subsection{Test tank}

The pile load tests were performed in steel test tank with inside dimensions of $800 \times 800 \mathrm{~mm}$ in plan and $800 \mathrm{~mm}$ in depth. The wall thickness of test tank is $4 \mathrm{~mm}$ to avoid any lateral deformation of the side walls. Test tank is connected directly with two steel columns using a special guide. These columns are firmly fixed in two horizontal steel beams, which are firmly stabled in the lab ground. In this present study, the internal dimensions of test tank were taken so as to minimize the boundary effect between soil grains and sides of the test tank. According to the related literature, the distance between the pile elements and the walls of test tank should be in excess of (10) times pile diameters as proposed by Phillips and Valsangkar [44] and Bolton et al. [7]. Furthermore, Garnier et al. [19] recommended that, the ratio between the width of test tank and the pile diameter should be in excess of (35). Therefore, the inner sizes of test tank were taken so as according to the recommended ratios.

Axial compression loads on different model piles were applied gradually in small increments using a hand operated hydraulic jack. The loads were measured using load cell to record the applied compression load. A steel plates were located centrally on the width of test tank to support base of magnetic bars for two dial gauges. Two dial gauges were stabled at equal distances from the pile axis. The readings of dial gauge were recorded form both dial gauges for each increment of compression loading when it becomes stable. The axial displacement of the pile corresponding to the applied axial compression load has been taken as the average value of displacement that recorded from both dial gauges. The experimental set up is shown in Fig. 1. During loading process and the pile installation methods, the soil surrounding the pile will be disturbed. This soil disturbance is extending to the concern zone depending to the method of pile installation technique and the sand relative density. This zone was found to be within the range of (3D-8D) from the pile tip, where D: pile diameter [47]. In this experimental work, the distance between the pile tip and the bottom of test tank is to be ranging from 10D to 30D that is in excess of the recommended ratio.

\subsection{Sand used}

The tests were performed on dry, commercially available sand at Tanta city/Egypt (longitude $31^{\circ} 00^{\prime} 04^{\prime \prime} \mathrm{E}$, and latitude $30^{\circ} 78^{\prime} 65^{\prime \prime} \mathrm{N}$ ). The sand used in this study is classified as poorly graded (SP) according to the Unified Soil Classification System. ASTM Specifications were performed in order to classify the sand used. Physical properties of the used sand are summarized in Table 1. The sand used has round particles that helped in minimizing the resistance between the test tank walls and soil. To maintain the influence of grain size distribution on the combined pile-soil interaction; Balachowski [5] proposed that, the ratio between the proposed model pile diameters (D) to the mean grain size diameter $\left(d_{50}\right)$ of the sand used must be in excess of (35) for vertical loading. In this model study, (D/d $\left.d_{50}\right)$ ratio is equal to 35.71 that is in excess of the recommended ratio. 
Table 1

Physical properties of the used sand

\begin{tabular}{|c|c|}
\hline Properties & Value \\
\hline Maximum unit weight, $\mathrm{Y}_{\max }\left(\mathrm{kN} / \mathrm{m}^{3}\right)$ & 19.14 \\
\hline O.M.C (\%) & 8.11 \\
\hline Minimum unit weight, $Y_{\min } .\left(\mathrm{kN} / \mathrm{m}^{3}\right)$ & 14.88 \\
\hline Specific gravity $\left(\mathrm{G}_{\mathrm{S}}\right)$ & 0.22 \\
\hline The effective grain size, $D_{10}(\mathrm{~mm})$ & 0.39 \\
\hline $\mathrm{D}_{30}(\mathrm{~mm})$ & 0.56 \\
\hline Mean grain size, $D_{50}(m m)$ & 0.66 \\
\hline $\mathrm{D}_{60}(\mathrm{~mm})$ & 3 \\
\hline Uniformity coefficient, $C_{u}$ & 1.05 \\
\hline Coefficient of curvature, $\mathrm{C}_{\mathrm{c}}$ & $\begin{array}{l}\text { SP } \\
41.2\end{array}$ \\
\hline Classification, USCS & 33.5 \\
\hline Maximum internal friction angle, $\varphi$ (degree) & 0.45 \\
\hline $\begin{array}{l}\text { Minimum internal friction angle, } \varphi \text { (degree) } \\
\text { Maximum void ratio, } e_{\max } \text {. } \\
\text { Minimum void ratio, } e_{\min } \text {. }\end{array}$ & 0.39 \\
\hline Modeling sand properties & \\
\hline Dense sand & \\
\hline Unit weight, $Y_{\text {dense }}\left(\mathrm{kN} / \mathrm{m}^{3}\right)$ & 18.11 \\
\hline $\begin{array}{l}\text { Relative density, } D_{r}(\%) \\
\text { Internal friction angle, } \varphi \text { (degree) }\end{array}$ & $\begin{array}{l}80 \\
40.1\end{array}$ \\
\hline Medium dense sand & \\
\hline Unit weight, $Y_{\text {medium dense }}\left(\mathrm{kN} / \mathrm{m}^{3}\right)$ & 17.17 \\
\hline Relative density, $D_{r}(\%)$ & 60 \\
\hline Internal friction angle, $\varphi$ (degree) & 36.9 \\
\hline Loose sand & \\
\hline Unit weight, $Y_{\text {loose }}\left(\mathrm{kN} / \mathrm{m}^{3}\right)$ & 16.06 \\
\hline Relative density, $\mathrm{D}_{\mathrm{r}}(\%)$ & 33 \\
\hline Internal friction angle, $\varphi$ (degree) & 35.2 \\
\hline
\end{tabular}

For conducting the experiments, sand layers were placed in $50 \mathrm{~mm}$ thick by using the predetermined weight method according to Salih et al. [49] and Rahil et al. [45]. The sand beds were placed for sand modeling purpose via the three chosen relative densities $\left(D_{r}\right)$ as loose sand $\left(D_{r}=33 \%\right)$, medium dense sand $\left(D_{r}=60 \%\right)$ and dense sand $\left(D_{r}=80 \%\right)$. To achieve the three cases of the relative sand densities, the predetermined weight of sand for each layer of $50 \mathrm{~mm}$ thick was placed and densified using a compacted solid plate hammer to the desired depth, which previously identified by lines drawn on the internal sides of steel test tank. The relative sand density achieved during the tests was monitored by collecting samples in small cans of known volume placed at different locations in test tank at the time of 
filling and sand density determined as Nazir and Nasr [42]. The relative sand densities obtained using cans were found to be within the range of $D_{r}=33 \% \pm 0.7 \%$ for the loose sand state, $D_{r}=60 \% \pm 1.22 \%$ for the medium dense sand state and $D_{r}=80 \% \pm 1.37 \%$ for the dense sand state.

\subsection{Model piles}

Seven different piles of open-ended pipe, closed-ended pipe and conical cross-sectional base pipe, square open-ended, square closedended, tapered and rectangular with $20 \mathrm{~mm}$ diameter/width are used as tested models as shown in Fig. 2 . The pile penetration depths were taken as 200 and $600 \mathrm{~mm}$. The model piles having (L/D ratio $\geq 23$ ) performances as long/flexible pile; while, the piles having ( $L / D$ ratio < 23) performances as short/rigid pile as recommended by Broms [8]. In the trend of (L/D) ratios, Lundberg et al. [32] proposed that, the $(L / D)$ ratio within the range of $(10-15)$ behaves as short/rigid pile; while, the (L/D) ratio within the range of (30-40) behaves as long/flexible pile. In order to simulate the performance of both short/rigid and long/flexible piles, the pile length to diameter (L/D) ratios were taken as 10 and 30 respectively. It should be noted that, the pile walls thickness (t) was $1.3 \mathrm{~mm}$ giving (D/t) ratio equal to 15.38 within the range of (15-45) for the open-ended pipe piles as suggested by Jardine and Chow [23]. In the trend of limitations, API [3] recommended that, the minimum wall thickness of used pile $(\mathrm{t})$ as expressed in Eq. (1) should not be less than:

$t=0.25+D / 100$

Where, D: pile diameter ( $\mathrm{mm}$ ). In this study, the pile walls thickness ( $\mathrm{t}$ ) was $1.3 \mathrm{~mm}$ that is in excess of the recommended minimum piling wall thickness. Furthermore, steel conical base has a sixty-degree configuration to close open-ended pipe piles. Finally, tapered piles (prismatic square) are consisted of a difference in axial width at their top and bottom along the length of model pile. Geometry configuration of model piles are shown in Table 2.

Table 2

Geometry configuration of model piles

\begin{tabular}{|c|c|c|c|c|c|}
\hline \multirow[t]{2}{*}{ Model piles } & \multicolumn{3}{|c|}{$\mathrm{D}$ or $\mathrm{B}(\mathrm{mm})$} & \multirow[t]{2}{*}{$L / D$} & \multirow[t]{2}{*}{$a\left(^{(}\right)$} \\
\hline & Pile head & Avg. & Pile tip & & \\
\hline Open-ended pipe pile (OEPP) & 20 & & & \multirow[t]{7}{*}{$10 \& 30$} & 0 \\
\hline Closed-ended pipe pile (CEPP) & 20 & & & & 0 \\
\hline Conical base pipe pile (CBPP) & 20 & & & & 0 \\
\hline Square open-ended pile (SOEP) & 20 & & & & 0 \\
\hline Square closed-ended pile (SCEP) & 20 & & & & 0 \\
\hline Tapered pile (TP) & 25 & 20 & 15 & & $1.43 \& 0.48$ \\
\hline Rectangular pile (RP) & 20 & & & & 0 \\
\hline
\end{tabular}

\subsection{Installation procedures of model pile}

After finishing the sand preparation inside the test tank, the location of model tested pile is achieved using a special guide that connected directly between the loading frame and test tank as shown in Fig. 3. Two method of installation techniques are done: jacking technique as shown in Fig. 3a and non-displacement technique as shown in Fig. 3b. At jacking technique, sand beds are prepared inside test tank; then, model pile located vertically on the top of sand using a special guide; finally, model pile installed in sand using a hydraulic compression jack to the desired depth. While, at non displacement technique, model pile placed vertically to the desired depth using a special guide; then sand beds were prepared into test tank.

\section{Testing Program}

After preparing sand and installing model pile vertically to the desired depth as described earlier, the axial compression loading tests were performed via hydraulic jack as shown in Fig. 1. The load was applied incrementally until the vertical settlement exceeded $25 \%$ of the used pile diameter or reaching failure. Eighty-four experiments were conducted on model piles in sand to investigate the influence of pile crosssection configuration on its axial compression load. Table 3 summarizes the testing program. 
Table 3

Testing program

\begin{tabular}{|c|c|c|c|c|c|}
\hline \multirow[t]{2}{*}{ Group } & \multirow[t]{2}{*}{ Series } & \multirow[t]{2}{*}{ Model pile condition } & \multicolumn{2}{|c|}{ Variable parameters } & \multirow{2}{*}{$\begin{array}{l}\text { No. of } \\
\text { tests }\end{array}$} \\
\hline & & & $\begin{array}{l}\text { Jacking } \\
\text { technique }\end{array}$ & $\begin{array}{l}\text { Non-displacement } \\
\text { technique }\end{array}$ & \\
\hline \multirow[t]{7}{*}{ Group (1): loose sand, $D_{r}=33 \%$} & $\mathrm{~S}_{1}$ & Open-ended pipe pile & \multirow{7}{*}{\multicolumn{2}{|c|}{$(\mathrm{L} / \mathrm{D})$ ratio $=10$ and 30}} & 4 \\
\hline & $\mathrm{S}_{2}$ & $\begin{array}{l}\text { Closed-ended pipe } \\
\text { pile }\end{array}$ & & & 4 \\
\hline & $\mathrm{S}_{3}$ & Conical base pipe pile & & & 4 \\
\hline & $\mathrm{S}_{4}$ & $\begin{array}{l}\text { Square open-ended } \\
\text { pile }\end{array}$ & & & 4 \\
\hline & $\mathrm{S}_{5}$ & $\begin{array}{l}\text { Square closed-ended } \\
\text { pile }\end{array}$ & & & 4 \\
\hline & $\mathrm{S}_{6}$ & Tapered pile & & & 4 \\
\hline & $\mathrm{S}_{7}$ & Rectangular pile & & & 4 \\
\hline \multirow{7}{*}{$\begin{array}{l}\text { Group (2): medium dense sand, } D_{r}= \\
60 \%\end{array}$} & $\mathrm{~S}_{8}$ & Open-ended pipe pile & \multirow{7}{*}{\multicolumn{2}{|c|}{$(\mathrm{L} / \mathrm{D})$ ratio $=10$ and 30}} & 4 \\
\hline & $\mathrm{S}_{9}$ & $\begin{array}{l}\text { Closed-ended pipe } \\
\text { pile }\end{array}$ & & & 4 \\
\hline & $\mathrm{S}_{10}$ & Conical base pipe pile & & & 4 \\
\hline & $\mathrm{S}_{11}$ & $\begin{array}{l}\text { Square open-ended } \\
\text { pile }\end{array}$ & & & 4 \\
\hline & $\mathrm{S}_{12}$ & $\begin{array}{l}\text { Square closed-ended } \\
\text { pile }\end{array}$ & & & 4 \\
\hline & $\mathrm{S}_{13}$ & Tapered pile & & & 4 \\
\hline & $\mathrm{S}_{14}$ & Rectangular pile & & & 4 \\
\hline \multirow[t]{7}{*}{ Group (3): dense sand, $D_{r}=80 \%$} & $\mathrm{~S}_{15}$ & Open-ended pipe pile & \multirow{7}{*}{\multicolumn{2}{|c|}{$(\mathrm{L} / \mathrm{D})$ ratio $=10$ and 30}} & 4 \\
\hline & $\mathrm{S}_{16}$ & $\begin{array}{l}\text { Closed-ended pipe } \\
\text { pile }\end{array}$ & & & 4 \\
\hline & $\mathrm{S}_{17}$ & Conical base pipe pile & & & 4 \\
\hline & $\mathrm{S}_{18}$ & $\begin{array}{l}\text { Square open-ended } \\
\text { pile }\end{array}$ & & & 4 \\
\hline & $\mathrm{S}_{19}$ & $\begin{array}{l}\text { Square closed-ended } \\
\text { pile }\end{array}$ & & & 4 \\
\hline & $\mathrm{S}_{20}$ & Tapered pile & & & 4 \\
\hline & $\mathrm{S}_{21}$ & Rectangular pile & & & 4 \\
\hline \multicolumn{3}{|l|}{ Total number of tests } & & & 84 \\
\hline
\end{tabular}

\section{Results And Discussion}

\subsection{Definition of failure load}

The ultimate axial capacities of model piles were estimated from load-relative displacement curves. The pile displacement, $\mathrm{S}(\mathrm{mm})$ is expressed in non-dimensional form in terms of pile diameter, $\mathrm{D}(\mathrm{mm})$ as percentage relative displacement ratio, S/D (\%). Terzaghi [52] and 
Meyerhof [37] proposed that, the ultimate axial pile capacities are estimated from the load-displacement curve as the load corresponding to relative displacement (S/D) equal to $10 \%$. Additionally, Das [12] described that, the maximum resistance at pile tip will not be mobilized until the pile tip has moved about $10-25 \%$ of the pile diameter. Due to no peak failure point specified at load-relative displacement curves is exhibited, the ultimate axial load of a single pile $\left(Q_{u l t}.\right)$ was estimated from load-relative displacement curves as the load corresponding to relative displacement (S/D) equal to $10 \%$.

\subsection{Load-displacement relationship}

To study the behavior of the axial capacity of a single pile, eighty-four tests were performed using seven different cross sections of piles with pile length equals to 200 and $600 \mathrm{~mm}$. From these tests, the load-displacement curves were obtained and presented in Figures (4 to 9). Figure 4 a shows typical axial compression load versus relative displacement, $S / D(\%)$ for different model piles having $L / D=10$ are installed in loose sand $\left(D_{r}=33 \%\right)$ using non-displacement technique. It is observed that, in the early phases of the loading, non-linearly relationship until relative displacement of approximately $20 \%$ then afterwards it is linear. It is also indicated that, the loading rate for openended pipe and square open-ended piles increased in the phases of the axial loading until the maximum $\left(\mathrm{Q}_{\text {axial }}\right)$ values approximately equal to $37.4 \mathrm{~N}$ and $59.7 \mathrm{~N}$ respectively corresponding to relative displacement of about $23.35 \%$ and $23.8 \%$ respectively. Afterwards, the loading rate is constant (more vertical settlement without additional load). The ultimate capacities ( $\mathrm{Q}_{\mathrm{ult}}$.) were found to be $57 \mathrm{~N}, 29 \mathrm{~N}$, $35.4 \mathrm{~N}, 63.5 \mathrm{~N}, 44.8 \mathrm{~N}, 50.8 \mathrm{~N}$ and $72.4 \mathrm{~N}$ for closed-ended pipe, open-ended pipe, conical base pipe, square closed-ended, square open-ended, tapered and rectangular piles respectively. Also Fig. $4 \mathrm{~b}$ shows typical axial compression load versus normalized displacement, S/D (\%) for different model piles having $L / D=30$ are installed in loose sand $\left(D_{r}=33 \%\right)$ using non-displacement technique. It is clear that, for square open-ended, square closed-ended, open-ended pipe and rectangular piles, in the early phases of the loading, non-linearly relationship until relative displacement of approximately $10 \%$ then afterwards it is linear. While, for closed-ended pipe, conical base pipe and tapered piles, non-linear relationship in the early stages of the loading until relative displacement of approximately $15 \%$ however afterwards it is linearly. It is indicated that, the loading rate for open-ended pile increased in the phases of the axial loading until the maximum $\left(Q_{\text {axial }}\right)$ value approximately equals to $95.3 \mathrm{~N}$ corresponding to relative displacement of about $28.85 \%$. Afterwards, the loading rate is constant (more vertical settlement without additional load). The corresponding ultimate capacities ( $\mathrm{Q}_{\text {ult. }}$ ) were found to $125 \mathrm{~N}, 62.2 \mathrm{~N}, 85.95 \mathrm{~N}, 115.3 \mathrm{~N}$, $106.9 \mathrm{~N}, 95.8 \mathrm{~N}$ and $144.7 \mathrm{~N}$ for closed-ended pipe, open-ended pipe, conical base pipe, square closed-ended, square open-ended, tapered and rectangular piles. Comparing between the results presented in Fig. $4 \mathrm{a}$ and Fig. $4 \mathrm{~b}$, it is found that, model piles with $\mathrm{L} / \mathrm{D}=30$ have more resistance than model piles with $L / D=10$. This observation due to that, the shaft resistance of model piles $\left(Q_{s}\right)$ increases with the increase of the surface area of pile per unit length. It is observed that, the load capacity of piles is highly affected by the pile length to diameter (L/D) ratio. In addition, Fig. 5a indicates load-relative displacement curves for different model piles with L/D = 10 are installed in loose sand $\left(D_{r}=33 \%\right)$ using jacking technique. It is clearly that, for open-ended pipe, conical base pipe, square open-ended, and square closed-ended piles, in the early phases of the loading, non-linearly relationship until relative displacement of approximately $20 \%$ however afterwards it is linearly. However, for tapered and closed-ended pipe piles, in the early phases of the loading, non-linearly relationship until relative displacement of approximately $15 \%$ then afterwards it is linearly. For rectangular pile, in the early phases of the loading, nonlinearly relationship until relative displacement of approximately $10 \%$ then afterwards it is linearly. The ultimate capacities $\left(\mathrm{Q}_{\mathrm{ult}}\right.$. $)$ were found to be $91.9 \mathrm{~N}, 45.6 \mathrm{~N}, 55.3 \mathrm{~N}, 73.1 \mathrm{~N}, 64.4 \mathrm{~N}, 81.4 \mathrm{~N}$ and $108.6 \mathrm{~N}$ for closed-ended pipe, open-ended pipe, conical base pipe, square closed-ended, square open-ended, tapered and rectangular piles. From the same figure, the ultimate axial capacity $\left(\mathrm{Q}_{\mathrm{ult}}\right.$. $)$ value of tapered pile was found to be increased by $11.35 \%$ compared with the $\left(\mathrm{Q}_{\mathrm{ult}}\right.$. $)$ value of square closed-ended pile. This observation due to that, the tapering degree $(a)$ of model pile increases the internal friction angle between pile and sand $(\delta)$ that has an influence on the taper coefficient $\left(\mathrm{K}_{\mathrm{t}}\right)$. It has been clearly observed that, for piles installed in sand via jacking method technique, the influence of tapering degree is highly affected on the axial pile capacity. On the other hand, Fig. $5 \mathrm{~b}$ illustrations load-relative displacement curves for different model piles with $L / D=30$ are installed in loose sand $\left(D_{r}=33 \%\right)$ using jacking technique. It is observed that, for open-ended pipe, conical base pipe, square open-ended, square closed-ended and closed-ended pipe piles, in the early phases of the loading, non-linearly relationship until relative displacement of approximately $10 \%$ then afterwards it is linearly. However, for tapered and rectangular piles, at the early phases of the loading, non-linearly relationship until relative displacement of almost $20 \%$ then afterwards it is linearly. It is also observed that, the loading rate for open-ended pipe and conical base pipe piles increased in the phases of the axial loading until the maximum $\left(Q_{\text {axial }}\right)$ values about equal to $128.9 \mathrm{~N}$ and $155.95 \mathrm{~N}$ respectively corresponding to relative displacement of about $15 \%$ and $21.65 \%$ respectively. Afterwards, the loading rate is constant (more vertical settlement without additional load). The corresponding ultimate capacities ( $\mathrm{Q}_{\mathrm{ult}}$ ) were found to be $298.9 \mathrm{~N}, 126.8 \mathrm{~N}, 150 \mathrm{~N}, 200.9 \mathrm{~N}, 166.7 \mathrm{~N}, 280 \mathrm{~N}$ and $340.7 \mathrm{~N}$ for closed-ended pipe, open-ended pipe, conical base pipe, square closed-ended, square open-ended, tapered and rectangular piles respectively. The same figure also indicates that; the ultimate axial capacity $\left(\mathrm{Q}_{\mathrm{ult}}\right.$ ) value of tapered pile was found to be increased by $39.37 \%$ compared with the $\left(\mathrm{Q}_{\mathrm{ult}}\right.$ ) value of square closed-ended pile. On the other hand, Fig. 6 a indicates the relationship of the axial compression load versus relative displacement curves

Page 7/30 
for different model piles having $L / D=10$ are installed in medium dense sand $\left(D_{r}=60 \%\right)$ using non-displacement technique. This figure indicates that, for open-ended pipe, conical base pipe, and square closed-ended piles, at the early phases of the loading, linearly relationship until relative displacement of almost $0.35 \%$ then it is non-linearly in phases of the axial loading until relative displacement of almost 15\%, afterwards it is linearly. The same figure also indicates that; at the early phases of the loading, linearly relationship for square open-ended, tapered, closed-ended pipe and rectangular piles until relative displacement of almost $0.30 \%$ then it is non-linearly relationship in phases of the axial loading until relative displacement of almost $10 \%$, afterwards it is linearly. It is observed that, the loading rate for open-ended pipe pile increased in the stages of the axial loading up to the maximum $\left(Q_{\text {axial }}\right)$ value approximately equal to $114.6 \mathrm{~N}$ corresponding to relative displacement of about $21.90 \%$. Afterwards, the loading rate is constant (more vertical settlement without additional load). The observed ( $\mathrm{Q}_{\mathrm{ult}}$.) results were found to be $215.8 \mathrm{~N}, 102.6 \mathrm{~N}, 115.1 \mathrm{~N}, 191.3 \mathrm{~N}, 136.9 \mathrm{~N}, 164 \mathrm{~N}$ and $226.8 \mathrm{~N}$ for closed-ended pipe, open-ended pipe, conical base pipe, square closed-ended, square open-ended, tapered and rectangular piles respectively. Also Fig. $6 \mathrm{~b}$ indicates load-relative displacement curves for different model piles with $L / D=30$ are installed in medium dense sand $\left(D_{r}=60 \%\right)$ using non-displacement technique. This figure indicates that, for open-ended pipe, square open-ended, and tapered piles, at the early phases of the loading, linearly relationship until relative displacement of almost $0.25 \%$ then it is non-linearly relationship in phases of the axial loading until relative displacement of approximately $10 \%$, afterwards it is linearly. The same figure also indicates that; at the early phases of the loading, linearly relationship for conical base pipe, closed-ended pipe, square closed-ended and rectangular piles until relative displacement of almost $0.20 \%$ then it is non-linearly relationship in phases of the axial loading until relative displacement of almost $5 \%$, afterwards it is linearly. It is also observed that, the loading rate for open-ended pipe and conical base pipe piles increased in the phases of the axial loading until the maximum $\left(Q_{\text {axial }}\right)$ values approximately equal to $141.3 \mathrm{~N}$ and $145.95 \mathrm{~N}$ respectively corresponding to relative displacement of about $11.15 \%$ and $11.60 \%$ respectively. Afterwards, the loading rate is constant (more vertical settlement without additional load). the corresponding capacities ( $\mathrm{Q}_{\mathrm{ult}}$.) were found to be $321.1 \mathrm{~N}, 140.7 \mathrm{~N}, 145.5 \mathrm{~N}, 341.3 \mathrm{~N}, 185.1 \mathrm{~N}, 280 \mathrm{~N}$ and $434.3 \mathrm{~N}$ for closed-ended pipe, open-ended pipe, conical base pipe, square closed-ended, square open-ended, tapered and rectangular piles respectively. It can be concluded that, the piles installed in medium dense sand have more resistance than piles installed in loose sand. This observation is due to that, the friction angle of sand $(\varphi)$ has a great influence on the shaft resistance of pile $\left(Q_{S}\right)$. It has been clearly observed that, the relative sand density has a major influence on the axial pile load capacity.

Furthermore, Fig. 7a indicates load-relative displacement curves for different model piles with L/D = 10 are installed in medium dense sand $\left(D_{r}=60 \%\right)$ using jacking technique. It is observed that, for open-ended pipe, conical base pipe, square open-ended, closed-ended pipe and tapered piles, at the early phases of the loading, linearly relationship until relative displacement of almost $0.20 \%$ then it is non-linearly in phases of the axial loading until relative displacement of almost $10 \%$, afterwards it is linearly. It is also indicated that, at the early phases of the loading, linearly relationship for square closed-ended and rectangular piles until relative displacement of almost $0.05 \%$ then it is non-linearly in phases of the axial loading until relative displacement of almost $5 \%$, afterwards it is linearly. The same figure also showed that, the loading rate for open-ended pipe and conical base pipe piles increased in the phases of the axial loading until the maximum $\left(\mathrm{Q}_{\text {axial }}\right)$ values approximately equal to $385.5 \mathrm{~N}$ and $465 \mathrm{~N}$ respectively corresponding to relative displacement of about $11.70 \%$ and $30 \%$ respectively. Afterwards, the loading rate is constant (more vertical settlement without additional load). The observed capacities $\left(\mathrm{Q}_{\text {ult }}\right.$. $)$ were found to be $553 \mathrm{~N}, 384.5 \mathrm{~N}, 439.1 \mathrm{~N}, 518 \mathrm{~N}, 492.7 \mathrm{~N}, 566 \mathrm{~N}$ and $600 \mathrm{~N}$ for closed-ended pipe, open-ended pipe, conical base pipe, square closed-ended, square open-ended, tapered and rectangular piles respectively. From the same figure, analyzing the relation between axial compression load and relative displacement for square closed-ended (SCEP) and closed-ended pipe (CEPP) piles, the ( $\left.\mathrm{Q}_{\text {axial }}\right)$ values equal to $285.95 \mathrm{~N}$ and $265.95 \mathrm{~N}$ respectively at relative displacement of about $0.05 \%$, the loading rate $\left(Q_{\text {rate }}\right)$ for $(S C E P)$ pile is greater than (CEPP) pile up to relative displacement of about $1.75 \%$ corresponding to axial load equal to $425.95 \mathrm{~N}$, then the $\left(\mathrm{Q}_{\text {rate }}\right)$ for $(\mathrm{CEPP})$ pile is greater than (SCEP) pile up to relative displacement of about $21.75 \%$ corresponding to axial load approximately equal to $600 \mathrm{~N}$, afterwards $\left(\mathrm{Q}_{\text {rate }}\right)(\mathrm{SCEP})$ pile is greater than (CEPP) pile. This observation due to that, square closed-ended pile has more the perimeter surface and tip cross section area than closed-ended pipe pile. Moreover, Fig. 7b indicates load-relative displacement curves for different model piles with $L / D=30$ are installed in medium dense sand $\left(D_{r}=60 \%\right)$ using jacking technique. It is observed that, for model piles, at the early phases of the loading, linearly relationship until relative displacement of almost $0.20 \%$ then it is non-linearly in phases of the axial loading until relative displacement of almost 10\%, afterwards it is linearly. It also observed that, the loading rate for open-ended pipe and conical base pipe piles increased in the phases of the axial loading until the maximum $\left(\mathrm{Q}_{\text {axial }}\right)$ values approximately equal to $457 \mathrm{~N}$ and $489 \mathrm{~N}$ respectively corresponding to relative displacement of about $15 \%$ and $12.40 \%$ respectively. Afterwards, the loading rate is constant (more vertical settlement without additional load). The corresponding ultimate capacities $\left(\mathrm{Q}_{\mathrm{ult}}\right.$.) were found to be $678.4 \mathrm{~N}, 453 \mathrm{~N}, 486 \mathrm{~N}, 610 \mathrm{~N}$, $510 \mathrm{~N}, 703.5 \mathrm{~N}$ and $777 \mathrm{~N}$ for closed-ended pipe, open-ended pipe, conical base pipe, square closed-ended, square open-ended, tapered and rectangular piles respectively. Comparing the results of tapered piles shown in Figures (5 and 7); it is found that, there is a large difference between the corresponding ultimate capacities $\left(\mathrm{Q}_{\mathrm{ult}}.\right)$. This observation due to that, the internal friction angle between pile and sand $(\delta)$ 
has an influence on the taper coefficient $\left(K_{t}\right)$ and friction angle of sand $(\varphi)$. It has been clearly observed that, the influence of tapering degree is highly affected on axial pile capacity by increasing the relative sand density. Figure 8a illustrations load-relative displacement curves for different model piles with $L / D=10$ are installed in dense sand $\left(D_{r}=80 \%\right)$ using non-displacement technique. It is clear that, for model piles, at the early phases of the loading, linearly relationship until relative displacement of almost $0.15 \%$ then it is non-linearly in phases of the axial loading until relative displacement of about $10 \%$, afterwards it is linearly. At normalized displacement ratio S/D of about $10 \%$, The corresponding ultimate capacities $\left(\mathrm{Q}_{\mathrm{ult}}\right.$.) were found to be $239.6 \mathrm{~N}, 172.4 \mathrm{~N}, 152.7 \mathrm{~N}, 219.6 \mathrm{~N}, 194.1 \mathrm{~N}, 210.9 \mathrm{~N}$ and $262.2 \mathrm{~N}$ for closed-ended pipe, open-ended pipe, conical base pipe, square closed-ended, square open-ended, tapered and rectangular piles respectively. The same figure also shows that; the $\left(Q_{\mathrm{ult}}\right.$. $)$ value of open-ended pipe pile was found to be increased by $12.90 \%$ compared with the $\left(\mathrm{Q}_{\mathrm{ult}} \cdot \mathrm{)}\right.$ value of conical base pipe pile. In contrast, conical cross-sectional base pipe pile has more resistance than open-ended pipe pile at the same conditions in the two cases of loose and medium sand. This observation may be due to that, the effect of soil plugging within open-ended pipe pile is significant increased the inner shaft resistance $\left(\mathrm{Q}_{\text {inner }}\right)$. Therefore, the total pile resistance was increased. On the other hand, Fig. 8b indicates load-relative displacement curves for different model piles with $L / D=30$ are installed in dense sand $\left(D_{r}=80 \%\right)$ using non-displacement technique. This figure indicates that, for model piles, at the early phases of the loading, linearly relationship until relative displacement of almost $0.15 \%$ then it is non-linearly in phases of the axial loading until relative displacement of almost $10 \%$, afterwards it is linear. The same figure also indicates that; the corresponding capacities ( $\mathrm{Q}_{\text {ult. }}$ ) were found to be $425 \mathrm{~N}, 259 \mathrm{~N}$, $172 \mathrm{~N}, 475 \mathrm{~N}, 312 \mathrm{~N}, 399 \mathrm{~N}$ and $486 \mathrm{~N}$ for closed-ended pipe, open-ended pipe, conical base pipe, square closed-ended, square open-ended, tapered and rectangular piles respectively. Furthermore, Fig. 9a indicates load-relative displacement curves for different model piles with $L / D=10$ are installed in dense sand $\left(D_{r}=80 \%\right)$ using jacking technique. It is observed that, for model piles, at the early phases of the loading, linearly relationship until relative displacement of almost $0.1 \%$ then it is non-linearly in phases of the axial loading until relative displacement of almost $10 \%$, afterwards it is linearly. The corresponding capacities ( $Q_{\text {ult }}$ ) were found to be $637 \mathrm{~N}, 425 \mathrm{~N}, 494 \mathrm{~N}, 594 \mathrm{~N}$, $541.7 \mathrm{~N}, 670 \mathrm{~N}$ and $756 \mathrm{~N}$ for closed-ended pipe, open-ended pipe, conical base pipe, square closed-ended, square open-ended, tapered and rectangular piles respectively. Finally, Fig. 9b indicates load-relative displacement curves for different model piles with L/D $=30$ are installed in dense sand $\left(D_{r}=80 \%\right)$ using jacking technique. It is observed that, at the early phases of the loading for open-ended pipe, square open-ended, square closed-ended and conical base pipe piles, linearly relationship until relative displacement of almost $0.15 \%$ then it is non-linearly in phases of the axial loading until relative displacement of about $10 \%$, afterwards it is linear. It is also observed that, at the early phases of the loading for closed-ended pipe, tapered and rectangular piles, linearly relationship until relative displacement of almost $0.10 \%$ then it is non-linearly in phases of the axial loading until relative displacement of almost $5 \%$, afterwards it is linearly. The corresponding ultimate capacities ( $\mathrm{Q}_{\mathrm{ult}}$.) were found to be $1035 \mathrm{~N}, 698 \mathrm{~N}, 954 \mathrm{~N}, 812 \mathrm{~N}, 746 \mathrm{~N}, 1111 \mathrm{~N}$ and $1248 \mathrm{~N}$ for closed-ended pipe, open-ended pipe, conical base pipe, square closed-ended, square open-ended, tapered and rectangular piles respectively. On the other hand, during the pile load test for conical base pipe pile, the vertical displacement readings of a two dial gauge were nearly identical. This observation due to the advantage of conical base that distributes the driven load evenly around the pile circumference and not causing added stresses on one section of the pile as described by Erhart [25]. In this model study, conical base pipe piles are used as a modified alternative to open-ended pipe piles to install piles into hard layer (dense sand, $D_{r}=80 \%$ ) using jacking technique. The results showed that, conical cross-sectional base pipe pile has more resistance than open-ended pipe pile. While, more investigations described that, the load capacity of open-ended pipe piles increase with increasing the pile diameters. Therefore, it should be designed and checked to ensure that the conical cross-sectional base pipe pile does not decrease the base load capacity of the plugging soil lower than the estimated value in the design as recommended by API [3].

\subsection{Influence of pile cross section}

To study the influence of the pile cross section on its axial capacity, seven different piles with the same geometry properties are used as tested models. The relation between axial compression load and relative displacement, S/D (\%) for the seven model piles are shown in Figures (4 to 9). These figures show that; the rectangular piles have the maximum resistance compared with the different model piles. It should be noted that; the rectangular pile is the optimization cross-sectional under the same pile geometry and soil conditions. The difference in axial pile capacities is referred to the change in the end bearing stress at the pile tip due to the different pile configurations which have different cross sectional area. And also, the radial stress around the pile perimeter due to the different pile cross sections that have a great influence in the earth pressure that highly affected on axial pile capacity. The summary of the values of ultimate axial compression capacity for different model piles in sand using non-displacement technique are presented in Tables 4 . For model piles with $\mathrm{L} / \mathrm{D}=10$ in sand using non-displacement technique, the ultimate axial capacity $\left(\mathrm{Q}_{\mathrm{ult}}\right)$ values of rectangular piles were found to be (1.27, $2.50,2.05,1.14,1.62$ and 1.43), (1.05, 2.21, 1.97, 1.19, 1.66 and 1.38) and $(1.09,1.52,1.72,1.19,1.35$ and 1.24$)$ times of the ( $Q_{\text {ult }}$.) values of closed-ended pipe, open-ended pipe, conical base pipe, square closed-ended, square open-ended and tapered piles in the cases of loose, medium dense and dense sand respectively. From the same figures, for model piles with $L / D=30$ in sand using non-displacement

Page 9/30 
technique, the ultimate axial capacity $\left(\mathrm{Q}_{\mathrm{ult}}\right)$ ) values of rectangular piles were found to be $(1.16,2.33,1.68,1.25,1.35$ and 1.51$),(1.35,3.09$, $2.98,1.27,2.35$ and 1.55$)$ and $\left(1.14,1.88,2.83,1.02,1.56\right.$ and 1.22) times of the $\left(\mathrm{Q}_{\mathrm{ult}}.\right)$ values of closed-ended pipe, open-ended pipe, conical base pipe, square closed-ended, square open-ended and tapered piles in the cases of loose, medium dense and dense sand respectively. While, for model piles with $L / D$ of 10 and 30 in sand using non-displacement technique, the ultimate axial capacity $\left(Q_{u l t}.\right)$ values of closed-ended pipe piles were found to be increased by (97\% and $101 \%),(110 \%$ and $128 \%$ ) and (39\% and $64 \%$ ) comparing with the $\left(\mathrm{Q}_{\mathrm{ult}}\right)$ values of open-ended pipe piles in the cases of loose, medium dense and dense sand respectively. Moreover, for piles with $L / D$ ratio of 10 and 30 in sand using non-displacement technique, the ultimate axial capacity $\left(\mathrm{Q}_{\mathrm{ult}}\right.$. $)$ values of closed-ended pipe piles were found to be increased by ( $61 \%$ and $45 \%),(87 \%$ and $121 \%)$ and $(57 \%$ and $147 \%)$ comparing with the $\left(\mathrm{Q}_{\text {ult }}\right.$. $)$ values of conical base pipe piles in the cases of loose, medium dense and dense sand respectively. Comparing between model piles having the same diameter; it is found that, the closed-ended pipe piles have more resistance comparing with the open-ended pipe [49] and conical base pipe piles. On the other hand, for piles with L/D of 10 and 30 in loose sand using non-displacement technique, the ultimate axial capacity ( $Q_{u \text { ult }}$ ) values of square closed-ended piles were found to be increased by $(42 \%$ and $25 \%)$ and ( $8 \%$ and $20 \%)$ comparing with the $\left(Q_{u l t}\right.$.) values of square open-ended and tapered piles respectively. While, these values were found to be increased by $(40 \%$ and $17 \%)$ and $(84 \%$ and $22 \%)$ in the case of medium dense sand. Finally, these values were found to be increased by (13\% and $4 \%)$ and $(52 \%$ and $19 \%)$ in the case of dense sand. Comparing between model piles with the same width are installed in sand using non-displacement technique; it is found that, the square closed-ended pile is a highly effective and more resistance compared with the square open-ended [22] and tapered piles. This observation due to square closed-ended piles have a large cross-sectional area at the tip pile. The summary of the values of ultimate axial compression capacity for different model piles in sand using jacking technique are presented in Tables 5. On the other hand, for model piles with $L / D=10$ in sand using jacking technique, the ultimate axial capacity $\left(Q_{u l t}\right)$ values of rectangular piles were found to be (1.18, $2.38,1.96,1.49,1.69$ and 1.33), $\left(1.08,1.56,1.37,1.16,1.22\right.$ and 1.06) and $\left(1.19,1.78,1.53,1.27,1.40\right.$ and 1.13) times of the ( $\left.Q_{u \text { ult }}\right)$ values of closed-ended pipe, open-ended pipe, conical base pipe, square closed-ended, square open-ended and tapered piles in the cases of loose, medium dense and dense sand respectively. The results indicated that, for model piles with $L / D=30$ in sand using jacking technique, the ultimate axial capacity $\left(\mathrm{Q}_{\mathrm{ult}}\right.$.) values of rectangular piles were found to be $(1.14,2.69,2.27,1.70,2.04$ and 1.22), $(1.15,1.72,1.60,1.27$, 1.52 and 1.10$)$ and $\left(1.21,1.79,1.31,1.54,1.67\right.$ and 1.12) times of the ( $Q_{u l t}$. values of closed-ended pipe, open-ended pipe, conical base pipe, square closed-ended, square open-ended and tapered piles in the cases of loose, medium dense and dense sand respectively. However, for model piles with L/D of 10 and 30 in sand using jacking technique, the ultimate axial capacity $\left(\mathrm{Q}_{\mathrm{ult}}\right.$.) values of closed-ended pipe piles were found to be increased by $(102 \%$ and $136 \%),(44 \%$ and $50 \%)$ and $(50 \%$ and $48 \%)$ comparing with the $\left(\mathrm{Q}_{\mathrm{ult}}\right.$. $)$ values of openended pipe piles in the cases of loose, medium dense and dense sand respectively. From the same figures, for model piles with L/D of 10 and 30 in sand using jacking technique, the ultimate axial capacity $\left(\mathrm{Q}_{\mathrm{ult}}\right.$.) values of closed-ended pipe piles were found to be increased by (66\% and $99 \%),(26 \%$ and $40 \%)$ and $(29 \%$ and $8 \%)$ comparing with the $\left(\mathrm{Q}_{\mathrm{ult}}\right)$ values of conical base pipe piles in the cases of loose, medium dense and dense sand respectively. Also, for piles with L/D of 10 and 30 in sand using jacking technique, the ultimate axial capacity $\left(Q_{u l t}\right.$. $)$ values of conical base pipe piles were found to be increased by $(21 \%$ and $18 \%),(14 \%$ and $7 \%)$ and $(16 \%$ and $37 \%)$ comparing with the $\left(\mathrm{Q}_{\mathrm{ult}}\right)$ values of open-ended pipe piles in the cases of loose, medium dense and dense sand respectively. In trend of tapering degree effect at jacking technique, it is found that, the values of ultimate axial capacity $\left(\mathrm{Q}_{\mathrm{ult}}\right.$.) for tapered piles with $\mathrm{L} / \mathrm{D}$ of 10 and 30 in loose sand were found to be increased by $(11 \%$ and $26 \%)$ and $(39 \%$ and $68 \%)$ comparing with the $\left(\mathrm{Q}_{\text {ult }}\right)$ values of square closedended and square open-ended piles respectively. Also, these values were found to be increased by ( $9 \%$ and $15 \%)$ and $(15 \%$ and $38 \%)$ in the case of medium dense sand. In addition, these values were found to be increased by (13\% and $24 \%$ ) and (37\% and $49 \%$ ) in the case of dense sand. These results are confirmed that, the tapered piles installed in sand using jacking technique have more resistance compared with the square closed-ended piles as described by Wei [56] and Wei and El-Naggar [56]. This observation due to the tapering degree increases the effective radius of influenced zone around the pile shaft. The densification of sand surrounding pile walls is produced additional lateral pressures led to increase the shear stresses through the pile-soil surface as indicated by Manandhar and Yasufuku [34]. The results indicated that, the tapering degree has a beneficial influence on the axial pile capacity. It should be noted that, geometry of pile toe has a significant influence on the ultimate compression load capacity and pile vertical displacement. 
Table 4

The ultimate axial compression capacities for model piles using non-displacement technique

\begin{tabular}{|c|c|c|c|c|c|c|c|c|c|c|c|c|c|c|}
\hline \multirow{3}{*}{$\begin{array}{l}\text { Relative } \\
\text { density }\end{array}$} & \multicolumn{14}{|c|}{ Ultimate axial compression load, $\mathrm{Qult}_{\mathrm{u} \cdot}(\mathrm{N})$} \\
\hline & \multicolumn{7}{|c|}{ Pile length to diameter $(L / D)$ ratio $=10$} & \multicolumn{7}{|c|}{ Pile length to diameter $(L / D)$ ratio $=30$} \\
\hline & CEPP & OEPP & CBPP & SCEP & SOEP & TP & RP & CEPP & OEPP & CBPP & SCEP & SOEP & $\mathrm{TP}$ & RP \\
\hline $\begin{array}{l}\text { Loose } \\
\text { sand } D_{r} \\
=33 \%\end{array}$ & 57 & 29 & 35.4 & 63.5 & 44.8 & 50.8 & 72.4 & 125 & 62.2 & 85.95 & 115.3 & 106.9 & 95.8 & 144.7 \\
\hline $\begin{array}{l}\text { Medium } \\
\text { dense } \\
\text { sand } D_{r} \\
=60 \%\end{array}$ & 215.8 & 102.6 & 115.1 & 191.3 & 136.9 & 164 & 226.8 & 321.1 & 140.7 & 145.5 & 341.3 & 185.1 & 280 & 434.3 \\
\hline $\begin{array}{l}\text { Dense } \\
\text { sand } D_{r} \\
=80 \%\end{array}$ & 239.6 & 172.4 & 152.7 & 219.6 & 194.1 & 210.9 & 262.2 & 425 & 259 & 172 & 475 & 312 & 399 & 486 \\
\hline
\end{tabular}

Table 5

The ultimate axial compression capacities for model piles using jacking technique

\begin{tabular}{|c|c|c|c|c|c|c|c|c|c|c|c|c|c|c|}
\hline \multirow{3}{*}{$\begin{array}{l}\text { Relative } \\
\text { density }\end{array}$} & \multicolumn{14}{|c|}{ Ultimate axial compression load, $\mathrm{Q}_{\mathrm{ult} \cdot}(\mathrm{N})$} \\
\hline & \multicolumn{7}{|c|}{ Pile length to diameter (L/D) ratio = 10} & \multicolumn{7}{|c|}{ Pile length to diameter (L/D) ratio = 30} \\
\hline & CEPP & OEPP & CBPP & SCEP & SOEP & TP & $\mathrm{RP}$ & CEPP & OEPP & CBPP & SCEP & SOEP & TP & $\mathrm{RP}$ \\
\hline $\begin{array}{l}\text { Loose } \\
\text { sand } D_{r} \\
=33 \%\end{array}$ & 91.9 & 45.6 & 55.3 & 73.1 & 64.4 & 81.4 & 108.6 & 298.9 & 126.8 & 150 & 200.9 & 166.7 & 280 & 340.7 \\
\hline $\begin{array}{l}\text { Medium } \\
\text { dense } \\
\text { sand } D_{r} \\
=60 \%\end{array}$ & 553 & 384.5 & 439.1 & 518 & 492.7 & 566 & 600 & 678.4 & 453 & 486 & 610 & 510 & 703.5 & 777 \\
\hline $\begin{array}{l}\text { Dense } \\
\text { sand } D_{r} \\
=80 \%\end{array}$ & 637 & 425 & 494 & 594 & 541.7 & 670 & 756 & 1035 & 698 & 954 & 812 & 746 & 1111 & 1248 \\
\hline
\end{tabular}

\subsection{Influence of relative sand density}

Figures (10 and 11) show the influence of relative sand density $\left(D_{r}\right)$ on the ultimate axial pile load. These figures give the relation between the ultimate axial load of different model piles and different relative sand densities. There are indicated that, the ultimate axial compression load of different model piles increases with the increase of relative sand density. Figure 10 shows the relation between the ultimate axial load of different model piles and different relative sand densities using non-displacement technique. It is observed that, for piles with L/D of 10 and 30, the ultimate axial load of piles in the case of medium dense sand were found to be increased by (2.79, 2.54 , $2.25,2.01,2.06,2.23$ and 2.13$)$ and $(1.57,1.26,0.69,1.96,0.73,1.92$ and 2.00$)$ compared with the ultimate axial load of piles in loose sand for the seven models of closed-ended pipe, open-ended pipe, conical base pipe, square closed-ended, square open-ended, tapered and rectangular piles respectively. It is also observed that, for piles with L/D of 10 and 30, the ultimate axial load of piles in the case of dense sand were found to be increased by $(3.20,4.94,3.31,2.46,3.33,3.15$ and 2.62$)$ and $(2.40,3.16,1.00,3.12,1.92,3.16$ and 2.36$)$ compared with the ultimate axial load of piles in loose sand for the seven models of closed-ended pipe, open-ended pipe, conical base pipe, square closed-ended, square open-ended, tapered and rectangular piles respectively. Furthermore, Fig. 11 shows the relation between the ultimate axial load of different model piles and different sand relative densities using jacking technique. This figure indicates that, for piles with L/D of 10 and 30, the ultimate axial load of piles in the case of medium dense sand were found to be increased by (5.02, 7.43, $6.94,6.09,6.65,5.95$ and 4.52$)$ and $(1.27,2.57,2.24,2.04,2.06,1.51$ and 1.28$)$ compared with the ultimate axial load of piles in loose 
sand for the seven models of closed-ended pipe, open-ended pipe, conical base pipe, square closed-ended, square open-ended, tapered and rectangular piles respectively. This figure also indicates that, for piles with L/D of 10 and 30, the ultimate axial load of piles in the case of dense sand were found to be increased by $(5.93,8.32,7.93,7.13,7.41,7.23$ and 5.96) and $(2.46,4.50,5.36,3.04,3.48,2.97$ and 2.66) compared with the ultimate axial load of piles in loose sand for the seven models of closed-ended pipe, open-ended pipe, conical base pipe, square closed-ended, square open-ended, tapered and rectangular piles respectively. It is mentioned that, the relative sand density is the most effective factor for axial pile capacity.

\subsection{Influence of (pile length/diameter) ratio}

The effect of (pile length/diameter) ratio, L/D on the ultimate axial load for different model piles was studied and presented in Figures (12 and 13). These figures indicate the relation of the ultimate axial load for model piles with different (pile length/diameter) ratio. These figures are indicated that, the ultimate axial load of model pile increases with the increase of the (pile length/diameter) ratio. Figure 12 illustrations the relation between the ultimate axial load of different model piles with different (pile length/diameter) ratio using nondisplacement technique. This figure indicates that, the values of the ultimate axial load of flexible piles $(L / D=30)$ in loose sand were found to be increased by $119 \%, 114 \%, 143 \%, 82 \% 139 \%, 89 \%$ and $100 \%$ compared with the values of the ultimate axial load of rigid piles $(L / D=10)$ for the seven models of closed-ended pipe, open-ended pipe, conical base pipe, square closed-ended, square open-ended, tapered and rectangular piles respectively. While, these values were found to be increased by $(49 \%, 37 \%, 26 \%, 78 \%, 35 \%, 71 \%$ and $91 \%)$ and $(77 \%, 50 \%, 13 \%, 116 \%, 61 \%, 89 \%$ and $85 \%)$ in the cases of medium dense and dense sand respectively. On the other hand, Fig. 13 shows the relation between the ultimate axial load of different model piles with different (pile length/diameter) ratio using jacking technique. This figure indicates that, the values of the ultimate axial load of flexible piles in loose sand were found to be increased by $225 \%, 178 \%, 171 \%, 175 \%, 159 \%, 244 \%$ and $214 \%$ compared with the values of the ultimate axial load of rigid piles for the seven models of closed-ended pipe, open-ended pipe, conical base pipe, square closed-ended, square open-ended, tapered and rectangular piles respectively. However, these percentage values were found to be increased by $(23 \%, 18 \%, 11 \%, 18 \%, 4 \%, 24 \%$ and $30 \%)$ and $(62 \%, 64 \%$, $93 \%, 37 \%, 38 \%, 66 \%$ and $65 \%)$ in the cases of medium dense and dense sand respectively. The results are shown in Figures (12 and 13$)$; these are indicated that, long/flexible model piles with $L / D=30$ have more resistance than short/rigid model piles with $L / D=10$. This observation due to that, the shaft resistance of model piles $\left(Q_{s}\right)$ increases with the increase of the surface area of pile per unit length. It is clearly indicated that, the compression pile load capacity is highly affected by the (pile length to diameter) ratio.

\subsection{Influence of pile installation technique}

So as to study the influence of pile installation technique on the ultimate axial load for model piles with different cross sections, Figures (14 and 15) are shown. These figures indicate the relation between the ultimate axial load for model piles with different cross sections and pile installation technique methods. These figures are indicated that, model piles installed in sand using jacking technique method have more resistance compared with model piles installed in sand using non-displacement technique method. Moreover, Fig. 14 indicates the relation between the ultimate axial load for model piles with different cross sections having pile length/diameter $(\mathrm{L} / \mathrm{D})$ ratio $=10$ and pile installation technique methods. This figure indicates that, the ultimate axial capacities of model piles installed in loose sand using jacking method were found to be increased by $61 \%, 57 \%, 56 \%, 15 \%, 44 \%, 60 \%$ and $50 \%$ compared with the ultimate axial capacities of model piles installed in sand using non-displacement method for the seven models of closed-ended pipe, open-ended pipe, conical base pipe, square closed-ended, square open-ended, tapered and rectangular piles respectively. Whereas, these percentages were found to be increased by $(156 \%, 275 \%, 281 \%, 171 \%, 260 \%, 245 \%$ and $165 \%)$ and $(166 \%, 147 \%, 224 \%, 170 \%, 179 \%, 218 \%$ and $188 \%)$ in the cases of medium dense and dense sand respectively. On the other hand, Fig. 15 indicates the relation between the ultimate axial load for model piles with different cross sections having pile length/diameter $(L / D)$ ratio $=30$ and pile installation technique methods. This figure indicates that, the ultimate axial capacities of model piles installed in loose sand using jacking method were found to be increased by $139 \%, 104 \%, 75 \%, 74 \%, 56 \%, 192 \%$ and $135 \%$ compared with the ultimate axial capacities of model piles installed in sand using nondisplacement method for the seven models of closed-ended pipe, open-ended pipe, conical base pipe, square closed-ended, square openended, tapered and rectangular piles respectively. However, these percentages were found to be increased by $(111 \%, 222 \%, 234 \%, 79 \%$, $176 \%, 151 \%$ and $79 \%)$ and $(144 \%, 169 \%, 455 \%, 71 \%, 139 \%, 178 \%$ and $157 \%)$ in the cases of medium dense and dense sand respectively. From Fig. 15c (in the case of dense sand), it is found that, the ultimate axial capacity of conical base pipe pile using jacking technique method is a highly increased by $455 \%$ compared with the ultimate axial capacity in case of non-displacement technique method. This observation approved that, the conical base with sixty-degree configuration is the preferred end closure for open-ended pipe piles to install piles in heavy or hard layers as proposed by Associated Pile and Fitting Company [4].

\section{Conclusion}


Based on the present investigation for studying the axial compression capacity of model piles with varied configuration in sand, the following conclusions can be drawn as follow:

1. Geometry of pile toe has a significant influence on the ultimate compression load capacity and pile vertical displacement.

2. Compression pile load capacity is highly affected by the pile length to diameter ratio.

3. The relative sand density is the most effective factor affecting the compression pile load capacity.

4. The tapering degree has a beneficial influence on the compression pile capacity.

5. The tapering degree is highly affected by the relative sand density, pile geometry and pile installation technique.

6. The load capacity of open-ended piles is greatly influenced by the degree of plugging soil.

7. The conical base distributes the driven load evenly around the pile circumference and not causing added stresses on one section of the pile.

8. The rectangular pile is the optimization cross-sectional under the same pile geometry and soil conditions.

9. For model piles with the same diameter at all conditions; the closed-ended pipe piles have more resistance compared with the openended pipe and conical base pipe piles.

10. For model piles with the same width are installed in sand using non-displacement technique; the square closed-ended pile is a highly effective and more resistance compared with the square open-ended and tapered piles.

11. Tapered piles driven in sand using jacking technique have more resistance compared with the square closed-ended piles.

12. Model piles driven in sand using jacking technique method have more resistance compared with model piles installed in sand using non-displacement technique method.

13. The conical base with sixty-degree configuration is the preferred end closure for open-ended pipe piles to install piles in heavy or hard layers.

\section{Declarations}

\section{Acknowledgments}

The experiments were carried out in the Geotechnical Laboratory of Structural Engineering Department, Tanta University which is acknowledges.

Conflict of interest On behalf of all authors, the corresponding author states that, there is no conflict of interest.

\section{Abbreviations}

\begin{tabular}{|ll|}
\hline$D_{r}$ & Relative sand density \\
L/D & Pile length to diameter ratio \\
$D$ & Pile diameter \\
$t$ & Pile walls thickness \\
$S$ & Pile displacement \\
S/D & Relative displacement \\
$Q_{\text {axial }}$ & Axial loading of pile \\
$Q_{u l t .}$ & Ultimate axial pile capacity \\
$Q_{s}$ & Shaft resistance of pile \\
$K_{t}$ & Taper coefficient \\
$\varphi$ & Internal friction angle of sand \\
$Q_{\text {rate }}$ & Inner shaft resistance of pile \\
$Q_{\text {inner }}$ & \\
\hline
\end{tabular}

\section{References}


1. Abdel-Salam SS, Baligh FA, El-Naggar HM (2016) Reliability and construction control of vibro piles. Ain Shams Engineering Journal, 7, Pp: 885-893

2. Adejumo TW (2015) Effects of shape and technology of installation on the bearing capacity of pile foundations in layered soil. Scholars Journal of Engineering and Technology (SJET), 3(2A), Pp: 104-111

3. American Petroleum Institute (API) (2007) Recommended Practice for Planning, Designing and Constructing Fixed Offshore Platforms. Washington, D.C: API RP2A, 22nd ed., American Petroleum Institute

4. Associated Pile and Fitting Company. APF-General Brochure-1017. Retrieved from : http://www.associatedpile.com/File\%20Library/Document\%20Library/English/Brochures/APF_General_Brochure_1017.pdf

5. Balachowski L (2006) Scale effect in shaft friction from the direct shear interface tests. Archives of Civil and Mechanical Engineering Journal, VI (3), Pp: 14-29

6. Basu P, Loukidis D, Prezzi M, Salgado R (2011) Analysis of shaft resistance of jacked piles in sands. Int J Numer Anal Meth Geomech 35:1605-1635

7. Bolton MD, Gui MW, Garnier J, Corte JF, Bagge G, Laue J, Renzi R (1999) Centrifuge cone penetration tests in sand. Ge'otechnique, 49(4), Pp: 543-552

8. Broms B (1964) The lateral resistance of piles in cohesive soils. Journal of the Soil Mechanics and Foundation Division, ASCE, 90(SM2), Pp: 27-63

9. Brucy F, Meunier J, Nauroy JF (1991) Behavior of pile plug in sandy soils during and after driving. International Proceeding 23rd Offshore Technology Conference, (Pp: 145-154). Houston, TX

10. Canakci H, Hamed M (2017) Experimental study on axial response of different pile materials in organic soil. Geomechanics and Engineering, 12(6), Pp: 899-917

11. Coyle HM, Castello RR (1981) New design correlations for piles in sand. Journal of the Geotechnical Engineering Division, American Society of Civil Engineers, 107(GT7), Pp: 965-986

12. Das BM (2014) Pile foundations. In: Principles of foundation engineering, Eighth Edition. Global Engineering; Nelson Education, United State of America, pp 391-504 In

13. De Beer E (1988) Different behaviour of bored and driven piles. Proceedings of the 1st International Geotechnical Seminar on Deep Foundations on Bored and Auger Piles (Pp: 47-82). Ghent: Balkema ed., Rotterdam

14. Deb P, Pal SK (2016) An experimental and numerical study on behaviour of single pile and group of piles in layered soils under vertical load. International Journal of Engineering Research and Technology (IJERT), 5(3), Pp: 200-208

15. Dharmatti V, Rakaraddi G (2014) An experimental study on vertically loaded driven and cast-in-situ piles. Journal of Mechanical and Civil Engineering (JMCE), 11(2), Pp: 43-48

16. Fattah MY, Al-Soudani WHS (2015) Bearing capacity of open-ended pipe piles with restricted soil plug. Ships and Offshore Structures, Taylor \& Francis Group, Pp, pp 1-16

17. Fattah MY, Al-Soudani WHS (2016) Bearing capacity of closed and open ended pipe piles installed in loose sand with emphasis on soil plug. Indian Journal of Geo-Marine Science, 45(5), Pp: 703-724

18. Fleming WOK, Weltman AJ, Randolph MF, Elson WK (1992) Piling engineering. Surrey University Press, London

19. Garnier J, Gaudin C, Springman SM, Culligan PJ, Goodings D, Konig D, Kutter B, Phillips R, Randolph MF, Thorel L (2007) Catalogue of scaling laws and similitude questions in geotechnical centrifuge modelling. International Journal of Physical Modelling in Geotechnics (IJPMG), 3, Pp: 1-23

20. Guo Y, Yu X (2016) Design and analyses of open-ended pipe piles in cohesionless soils. Front. Struct. Civ. Eng., 10(1), Pp: 22-29

21. Han F, Ganju E, Salgado R, Prezzi M, Zaheer M (2019) Experimental study of the load response of large diameter closed-ended and open-ended pipe piles installed in alluvial soil. Joint Transportation Research Program, Indiana Department of Transportation, West Lafayette

22. Ibrahim SF, Al-Soud MS, Al-Asadi FI (2018) Performance of a single pile under combined axial and lateral loads in layered sandy soil. Journal of Engineering and Sustainable Development, 22(1), Pp: 121-136

23. Jardine RJ, Chow FC (2007) Some recent development in off-shore pile design. 6th of Offshore Site Investigation Geotechnics Conference. London

24. Jebura AA, Athertona W, Alkhadara RM, Loffilla E (2017) Piles in sandy soil: A numerical study and experimental validation. Procedia Engineering Journal, 196, Pp: 60-67

Page $14 / 30$ 
25. Erhart J (2016, December 22) Conical Points for ERW Pipe Piles. Retrieved from Atlas Observer: https://www.atlastube.com/atlasobserver/conical-points-for-erw-pipe-piles/

26. Kim S, Whang SW, Kim S (2017) Pile foundation design through the increased bearing capacity of extended end pile. Journal of Asian Architecture and Building Engineering (JAABE), 16(2), Pp: 395-402

27. Kishida $H$, Uesugi $M$ (1987) Tests of the interface between sand and steel in the simple shear apparatus. Geotechnique, 37(1), Pp: 45-52

28. Klotz U (2000) The influence of state on the capacity of driven piles in sands. Ph. D. Thesis submitted to City University, London

29. Kraft LM (1991) Performance of axially loaded pipe pile in sand. Journal of Geotechnical Engineering, 117(2), Pp: 272-296

30. Kraft LM, Lyons CG (1990) State of the art: Ultimate axial capacity of grouted piles. Proc. 6th Annual OTC (Pp: 487-503). Houston: Paper OTC 2081

31. Liew SS, Ho SF (2016) Fallacy of capacity performance and innovation improvement of jack-in piling in Malaysia. Geotechnical Engineering Journal of the SEAGS \& AGSSEA, 47(4), Pp: 134-144

32. Lundberg AB, Dijkstra J, Tol FV (2012) On the modelling of piles in sand in the small geotechnical centrifuge. Eurofuge Conference Proceedings (Pp: 1-10). Delft University of Technology and Deltares

33. Manandhar S, Yasufuku N, Omine K, Kobayashi T (2010) Response of tapered piles in cohesionless soil based on model tests. Journal of Nepal Geological Society, 40, Pp: 85-92

34. Manandhara S, Yasufukub N (2013) Vertical bearing capacity of tapered piles in sands using cavity expansion theory. Soils and Foundations Journal, The Japanese Geotechnical Society, 53(6), Pp: 853-867

35. Mansur $\mathrm{Cl}$, Hunter AH (1970). Pile Tests-Arkansas river project. Journal of the Soil Mechanics and Foundations Division, American Society of Civil Engineers, 96(SM6), Pp: 1545-1582

36. McClelland B (1974) Design of deep penetration piles for ocean structures. Journal of the Geotech. Engineering Division, ASCE, 100(GT7), Pp: 705-747

37. Meyerhof GG (1976) Bearing capacity and settlement of pile foundations. Journal of the Geotechnical Engineering Division, American Society of Civil Engineers, 102(GT3), Pp: 197-228

38. Meyerhof GG, Adams JI (1961) The ultimate uplift capacity of foundations. Canadian geotechnical journal, 5(4), Pp: 225-244

39. Mijena EH (2012) A comparison of friction piles bearing capacity based on theoretical and empirical mathematical models. Department of Civil and Transport Engineering, Norwegian University of Science and Technology

40. Murthy VNS (2003) Geotechnical engineering: principles and practices of soil mechanics and foundation engineering. Marcel Dekker, Inc., New York

41. Navfac, DM-7.2 (1982) Foundations and earth structures, Design Manual. Dept. of Navy, USA

42. Nazir A, Nasr A (2013) Pullout capacity of batter pile in sand. Journal of Advanced Research, 4, Pp: 147-154

43. Paik K, Salgado R, Lee J, Kim B (2003) Behavior of open- and closed-ended piles driven into sands. Journal of Geotechnical and Geoenvironmental Engineering, 129(4), Pp: 296-306

44. Phillips R, Valsangkar AJ (1987) Technical report: An experimental investigation of factors affecting penetration resistance in granular soils in centrifuge modeling. Dept. of Engineering, Cambridge Univ., England

45. Rahil FH, Al-Neami MA, Al-Zaho KAN (2016) Effect of relative density on behavior of single pile and piles groups embedded with different lengths in sand. Eng. \&Tech. Journal, 34(A), Pp: 1206-1215

46. Randolph MF (1994) Design methods for pile groups and piled rafts. 13th International Conference On Soil Mechanics and Foundation Engineering. 5, Pp: 61-82. New Delhi: ICSMFE

47. Robinsky El, Morrison CF (1964) Sand displacement and compaction around model friction piles. Can. Geotech. J., 1(2), Pp: 81-93

48. Sakr MA, Azzam WR, Kassim HK (29th March-1st April, 2021) Model study of jacked pile with varied geometry in sand. International Conference on Advances in Structural and Geotechnical Engineering (ICASGE'21) (Pp: 1-13). Hurghada: Faculty of Engineering, Tanta University, Egypt

49. Salih SJH, Salih NB, Noory DB (2020) Optimum design of steel piles in different sandy soil configurations. An International Journal of Geomechanics and Geoengineering, Pp: 1-22

50. Shahin MA (2016) State-of-the-art review of some artificial intelligence applications in pile foundations. Geoscience Frontiers Journal, 7(1), Pp: 33-44

51. Terzaghi K, Peck RB, Mesri G (1996) Soil mechanics in engineering practice, 3rd edn. Wiley-Interscience, New York

Page $15 / 30$ 
52. Terzaghi K (1943) Theoretical Soil Mechanics. J. Wiley and Sons, Inc, New York

53. Terzaghi K (1967) From theory to practice in soil mechanics; Selections from the writings of Karl Terzaghi, with bibliography and contributions on his life and achievents. John Wiley and Sons

54. Vesic AS (1970) Tests on instrumental Piles-Ogeechee river site. Journal of the Soil Mechanics and Foundations Division, American Society of Civil Engineers, 96(SM2), Pp: 561-584

55. Vesic AS (1977) Design of pile foundations. Washington, D.C.: National Cooperative Highway Research Program, Synthesis of Practice No. 42, Transportation Research Board

56. Wei J (1998) Experimental investigation of tapered piles. Master Degree Thesis submitted to The University of Western Ontario, London, Ontario, Canada: National Library of Canada

57. Wei J, El-Naggar MH (1998) Experimental study of axial behaviour of tapered piles. Canadian Geotechnical Journal, 35, Pp: 641-654

58. White DJ, Deeks AD (2007) Recent research into the behaviour of jacked foundation piles. Proceedings of the International Workshop on Recent Advances in Deep Foundations. Yokosuka, Japan

59. Wrana B (2015) Pile load capacity - calculation methods. Studia Geotechnica et Mechanica, 37(4), Pp: 83-93

60. Yang J, Tham LG, Lee PKK, Chan ST, Yu F (2006) Behaviour of jacked and driven piles in sandy soil. Ge'otechnique, 56(4), Pp: 245259

\section{Figures}

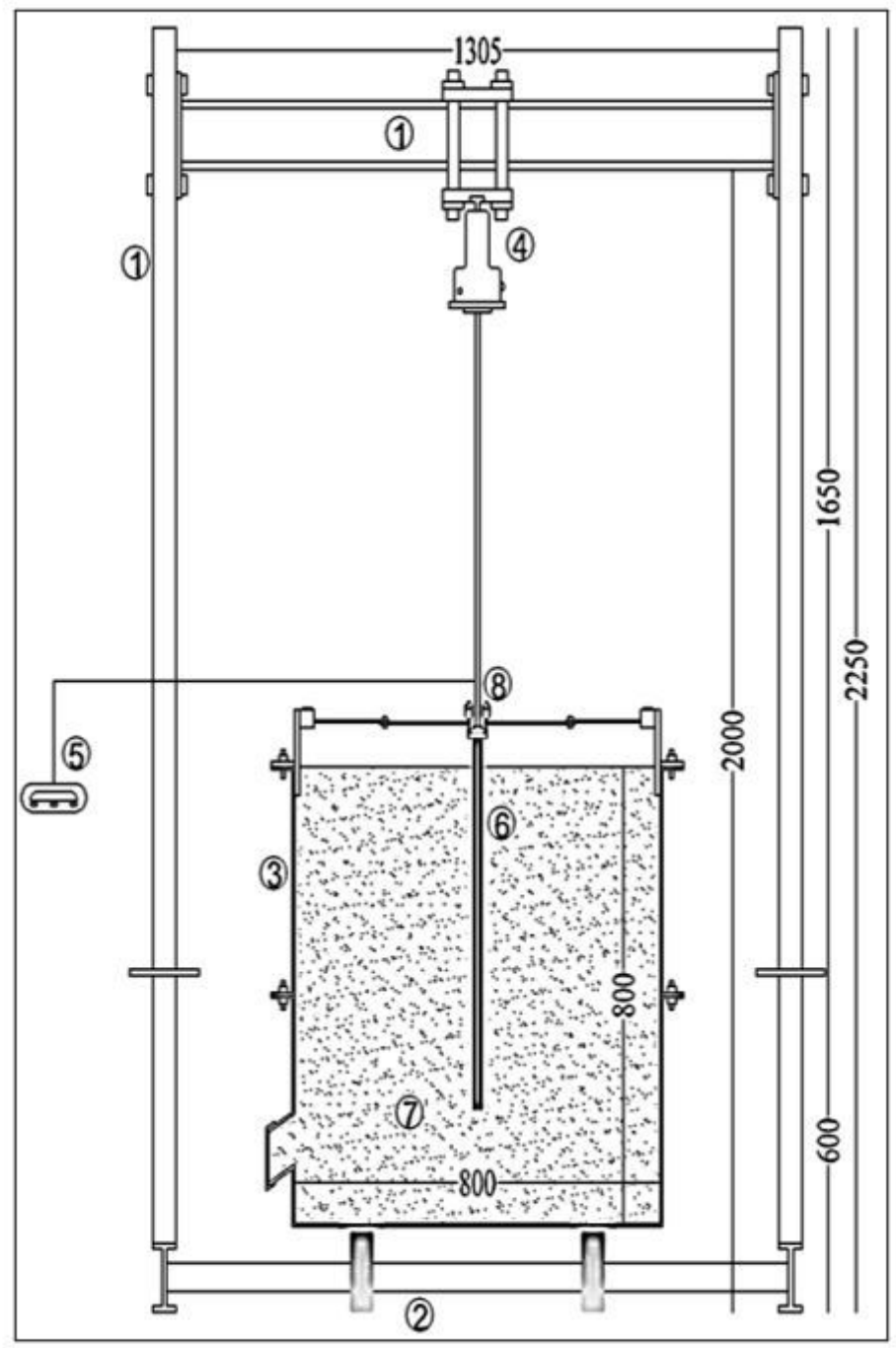

Figure 1

Page 16/30 
The experimental set up (1) Loading frame, (2) Base of loading frame, (3) Test tank, (4) Hydraulic jack, (5) Load cell, (6) Model pile, (7) Sand and (8) Dial gauges

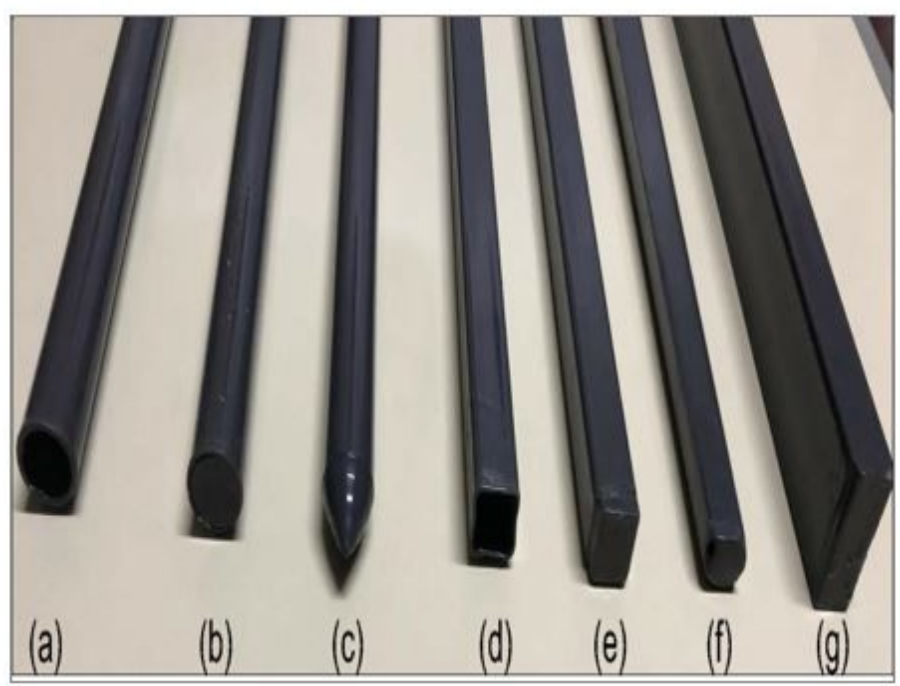

Figure 2

a - Open-ended pipe pile (OEPP). b - Closed-ended pipe pile (CEPP). $c$ - Conical base pipe pile (CBPP). $d$ - Square open-ended pile (SOEP). e - Square closed-ended pile (SCEP). $f$ - Tapered pile (TP). g - Rectangular pile (RP). Fig. 2 Model piles with different cross sections 


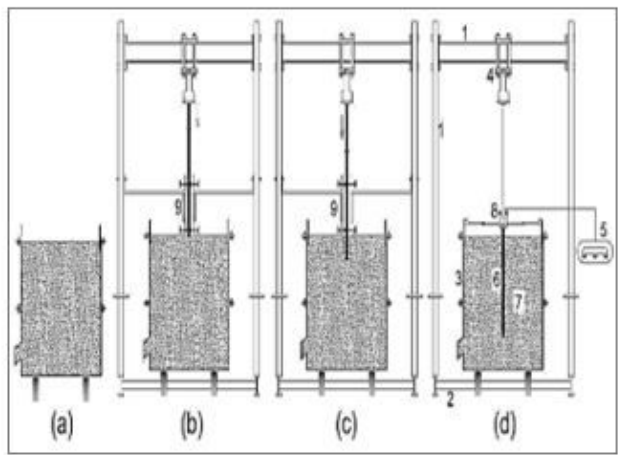

a) Jacking technique

a - Completing the $s$ and bed preparation inside the test tank.

b-Placing model pile vertically on the top of sand via a special guide.

c - Installing model pile in sand using a hydraulic jack.

d-Completing experimental setup before testing.

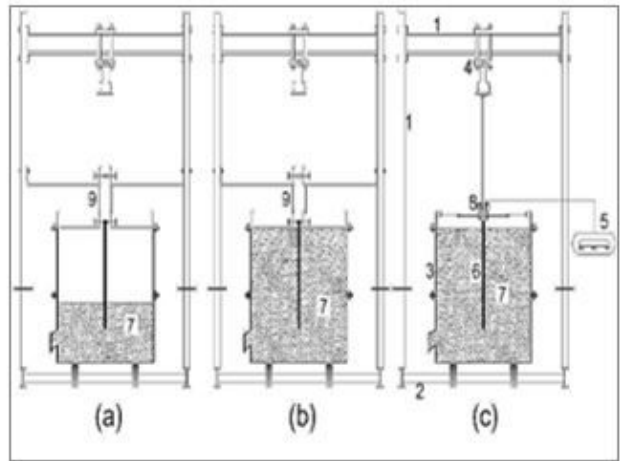

b) Non-displacement technique

\begin{abstract}
a - Placing model pile vertically to the desired depth via a special guide.
$\mathrm{b}$ - Completing the sand bed preparation inside the test tank.

c-Completing experimental setup before testing.
\end{abstract}

\title{
Figure 3
}

Installation procedures of model pile (1) Loading frame, (2) Base of loading frame, (3) Test tank, (4) Hydraulic jack, (5) Load cell, (6) Model pile, (7) Sand, (8) Dial gauges and (9) Special guide 


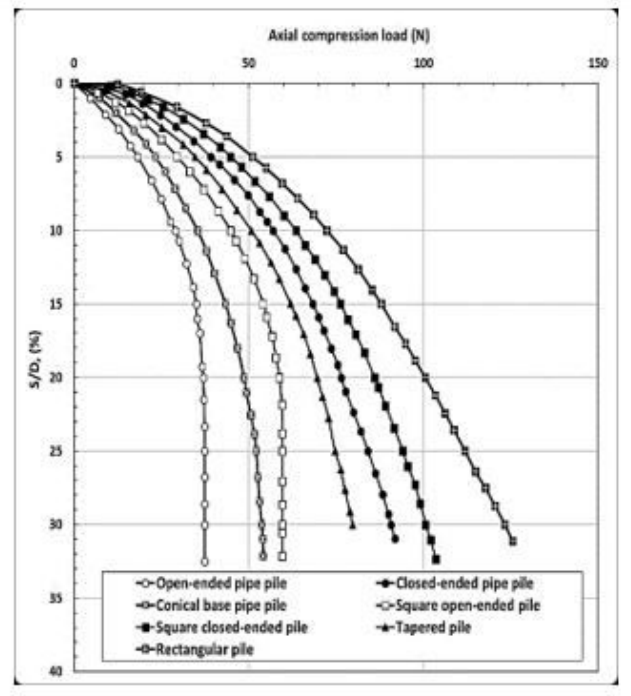

a) Pile length/diameter $(\mathrm{L} / \mathrm{D})$ ratio $=10$

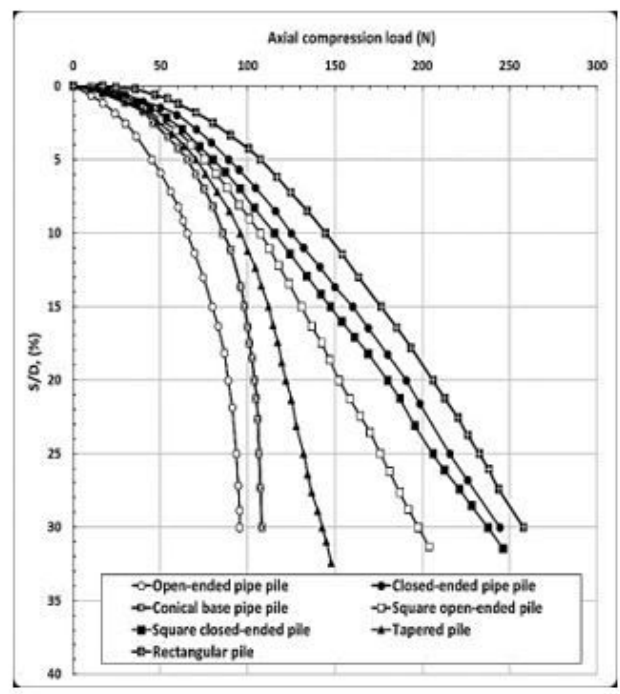

b) Pile length/diameter $(\mathrm{L} / \mathrm{D})$ ratio $=30$

\section{Figure 4}

Relation between axial compression load and relative displacement, S/D (\%) for different model piles in loose sand ( $\mathrm{Dr}=33 \%)$ using nondisplacement technique 


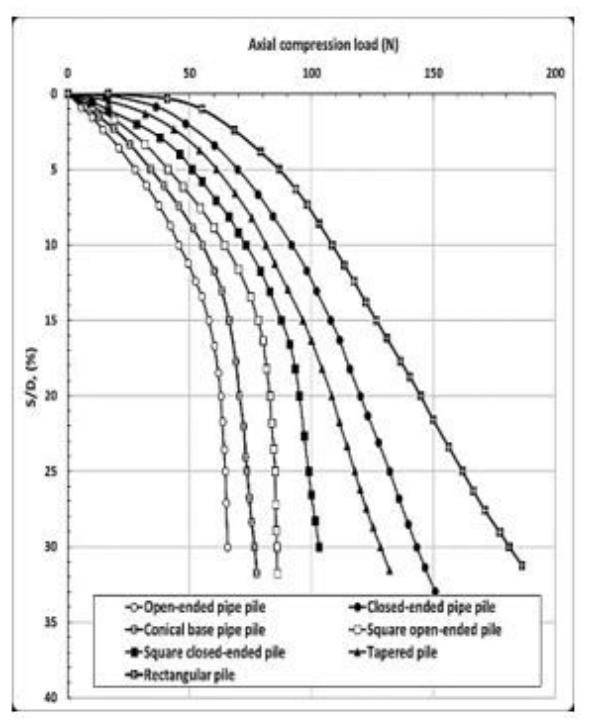

a) Pile length $/$ diameter $(L / D)$ ratio $=10$

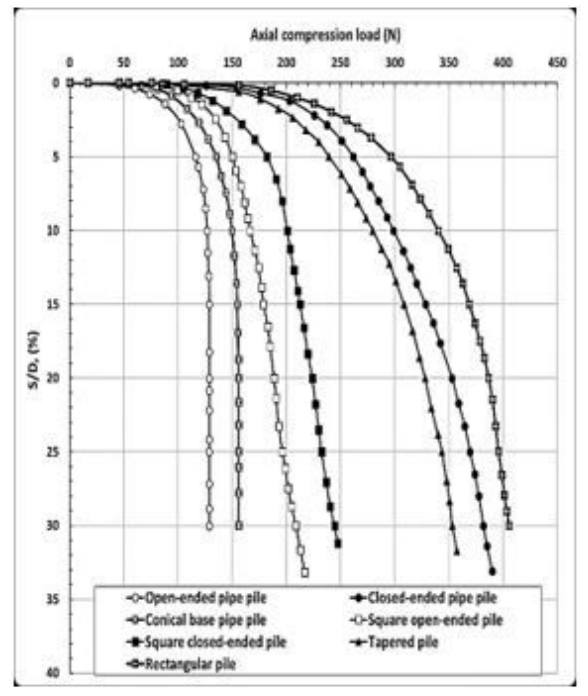

b) Pile length/diameter (L/D) ratio $=30$

\section{Figure 5}

Relation between axial compression load and relative displacement, S/D (\%) for different model piles in loose sand (Dr= 33\%) using jacking technique 


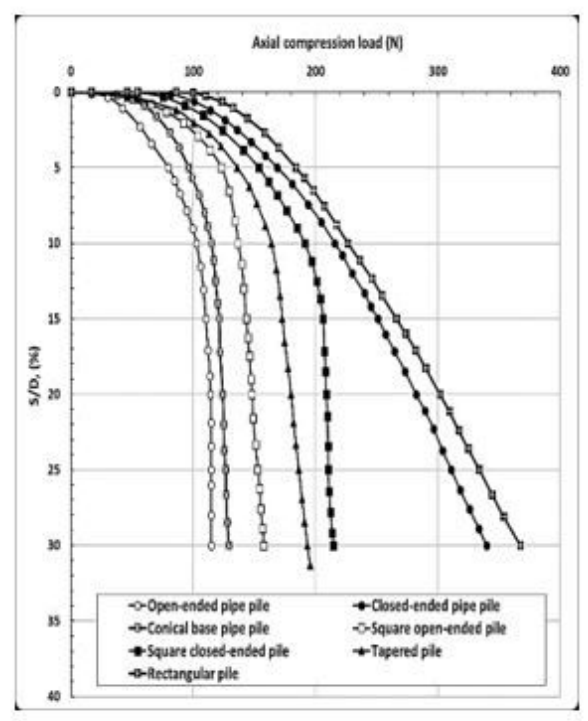

a) Pile length/diameter $(L / D)$ ratio $=10$

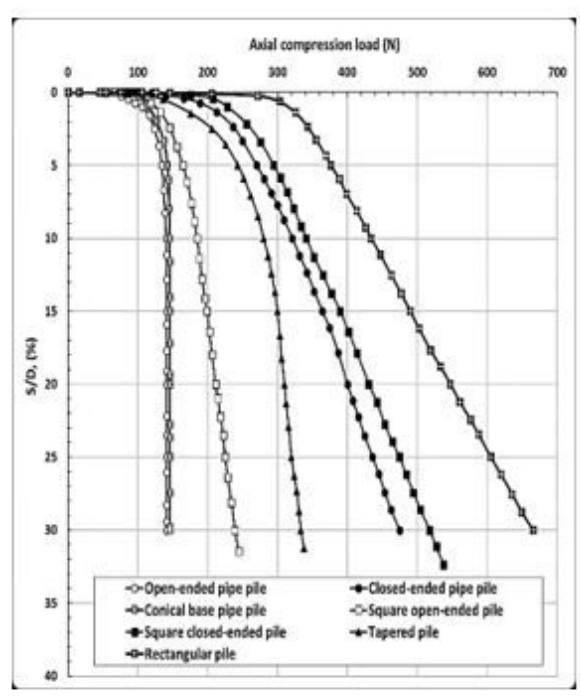

b) Pile length $/$ diameter $(L / D)$ ratio $=30$

\section{Figure 6}

Relation between axial compression load and relative displacement, S/D (\%) for different model piles in medium dense sand $(\mathrm{Dr}=60 \%)$ using non-displacement technique 


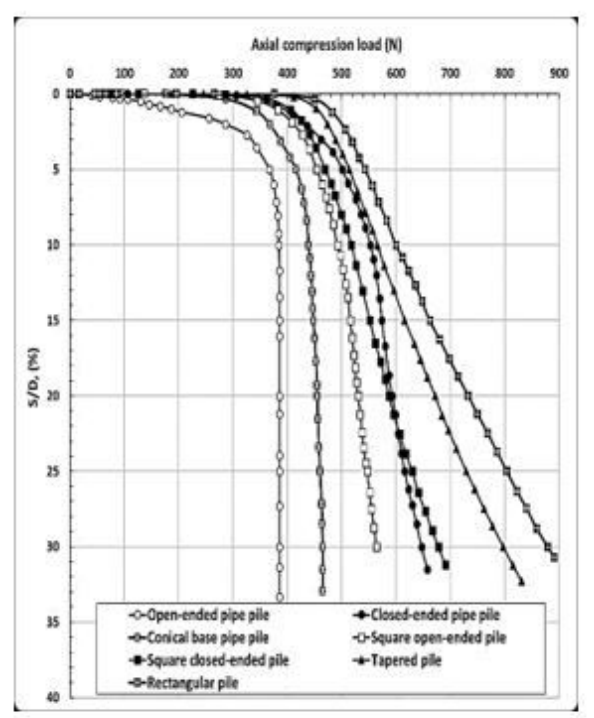

a) Pile length/diameter $(L / D)$ ratio $=10$

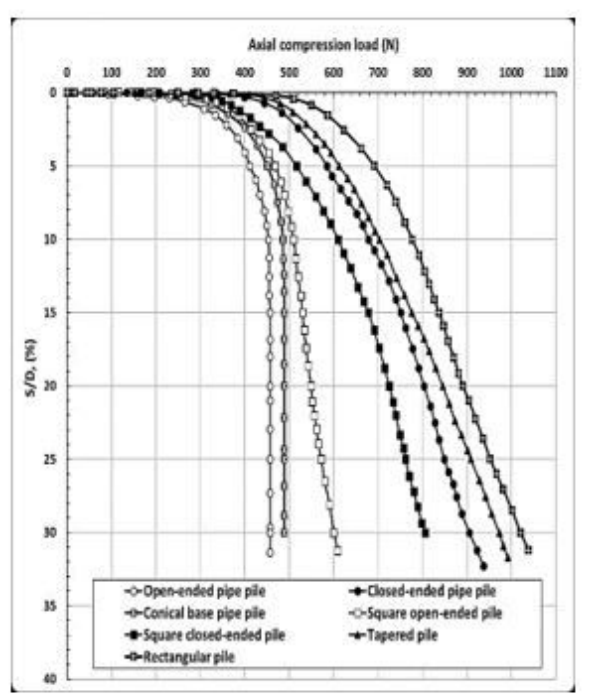

b) Pile length/diameter $(L / D)$ ratio $=30$

Figure 7

Relation between axial compression load and relative displacement, S/D (\%) for different model piles in medium dense sand (Dr= $60 \%)$ using jacking technique 


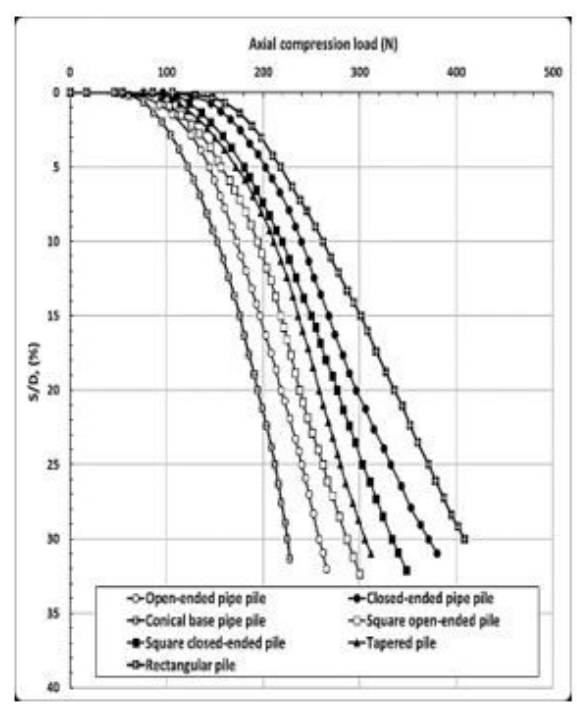

a) Pile length/diameter $(L / D)$ ratio $=10$

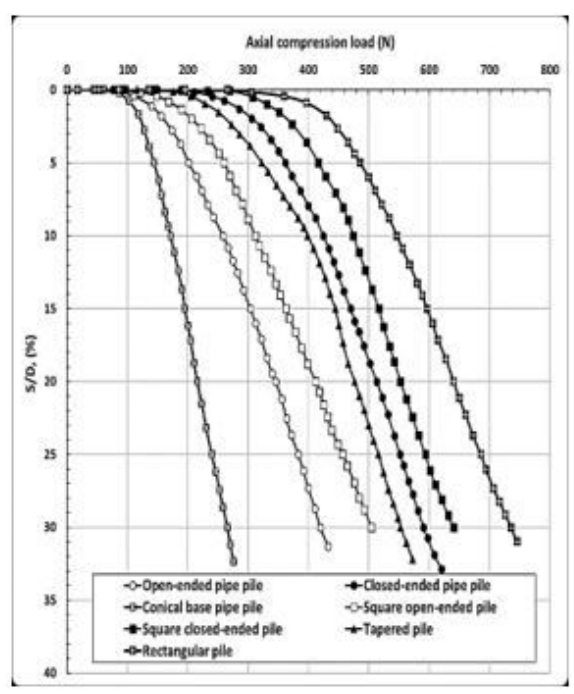

b) Pile length/diameter $(L / D)$ ratio $=30$

\section{Figure 8}

Relation between axial compression load and relative displacement, S/D (\%) for different model piles in dense sand (Dr= $80 \%)$ using nondisplacement technique 


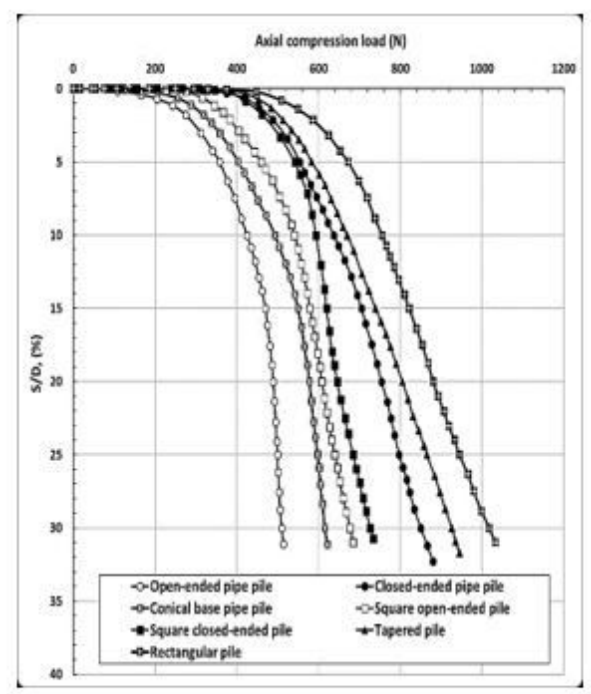

a) Pile length/diameter $(L / D)$ ratio $=10$

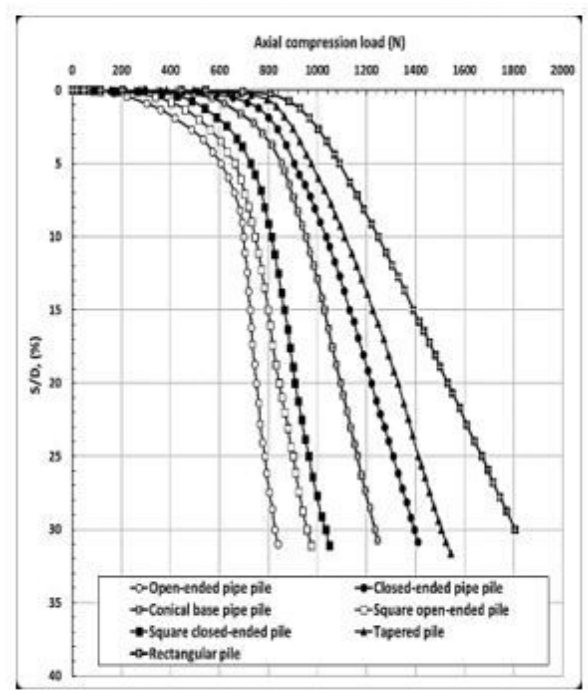

b) Pile length/diameter $(\mathrm{L} / \mathrm{D})$ ratio $=30$

Figure 9

Relation between axial compression load and relative displacement, S/D (\%) for different model piles in dense sand (Dr= $80 \%)$ using jacking technique 


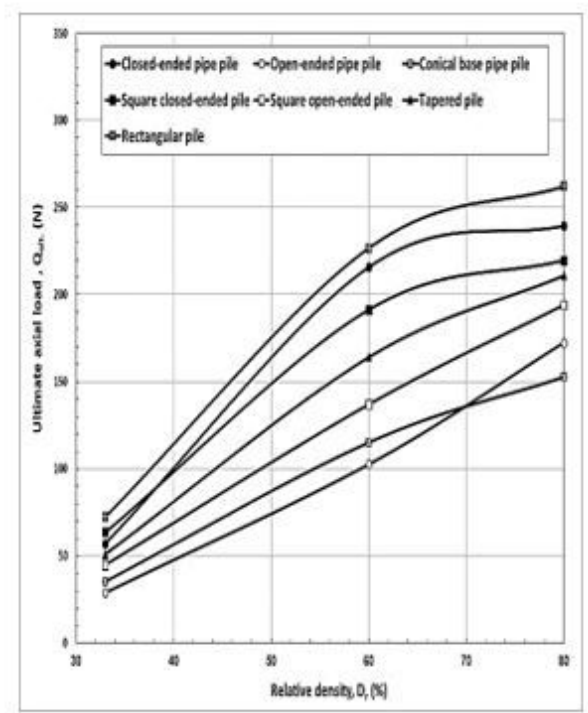

a) Pile length/diameter $(L / D)$ ratio $=10$

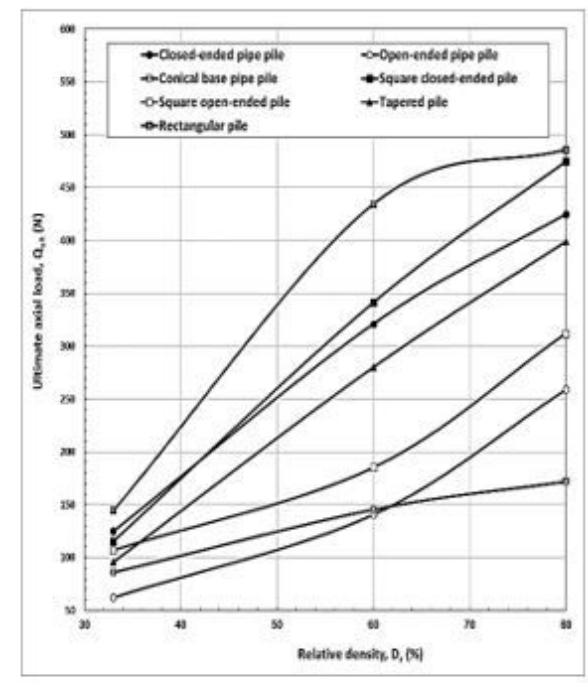

b) Pile length/diameter (L/D) ratio $=30$

Figure 10

Variation of ultimate axial load of different model piles with sand relative density using non-displacement technique 


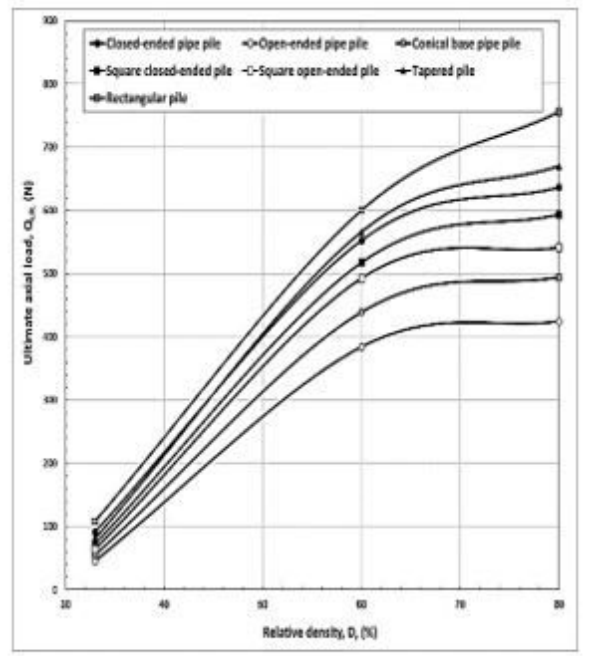

a) Pile length $/$ diameter $(L / D)$ ratio $=10$

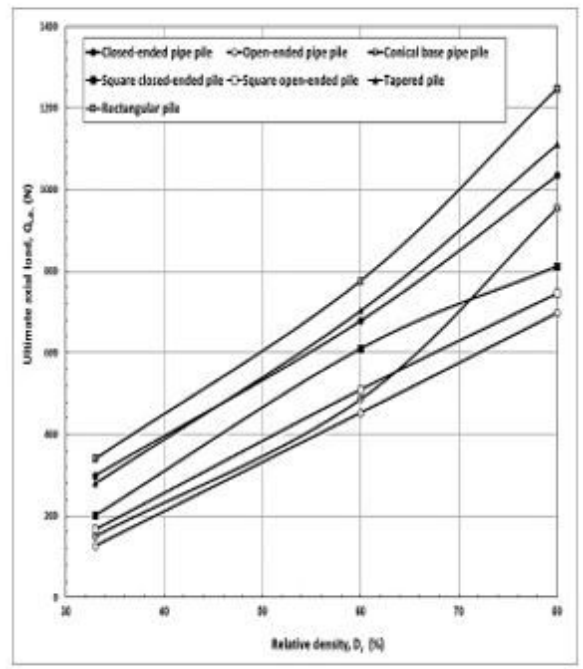

b) Pile length/diameter $(L / D)$ ratio $=30$

\section{Figure 11}

Variation of ultimate axial load of different model piles with sand relative density using jacking technique 


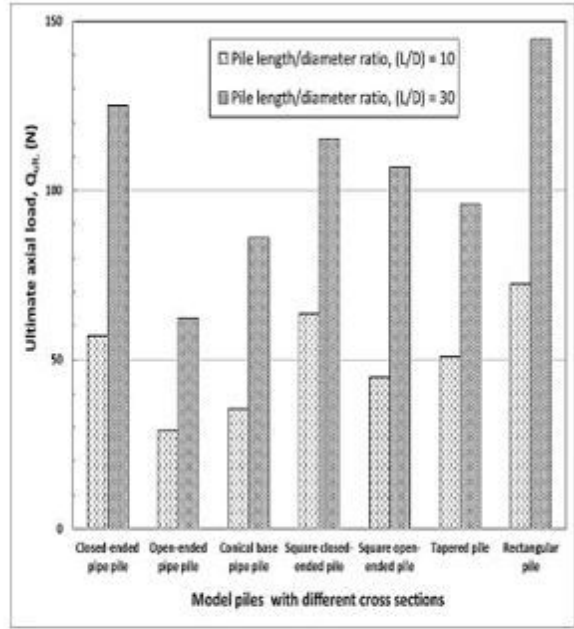

a) Loose sand, $D_{r}=33 \%$

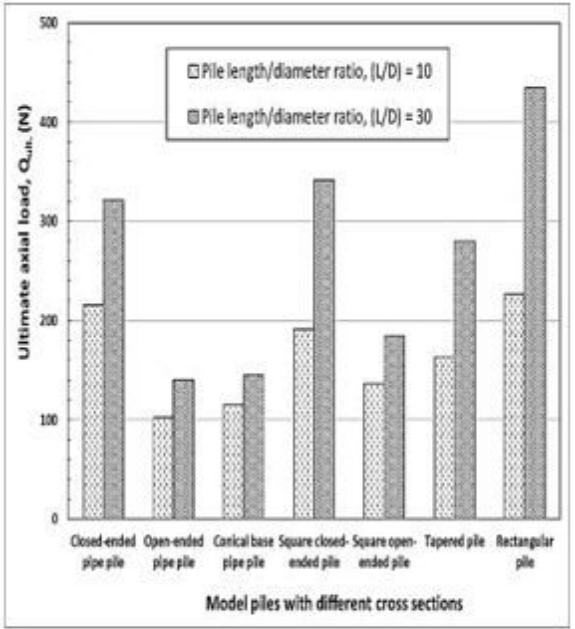

b) Medium dense sand, $D_{\text {s }}=60 \%$

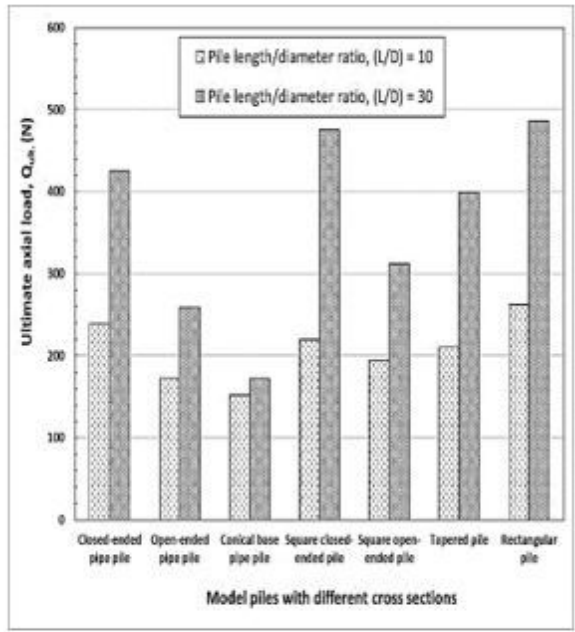

c) Dense sand, $D_{r}=80 \%$

\section{Figure 12}

Values of ultimate axial load of different model piles with different pile length/diameter (L/D) ratio using non-displacement technique 


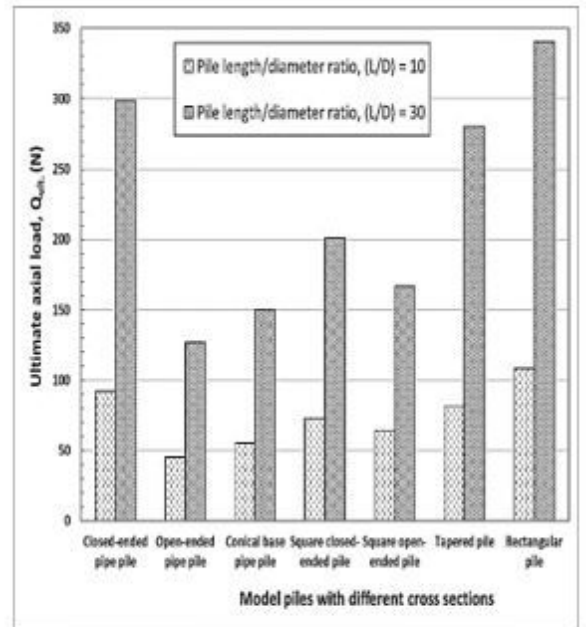

a) Loose sand, $D_{\mathrm{r}}=33 \%$

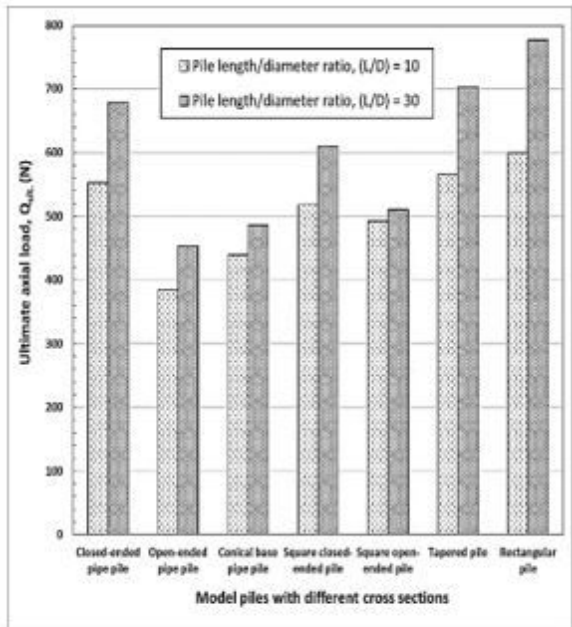

b) Medium dense sand, $\mathrm{D}_{\mathrm{x}}=60 \%$

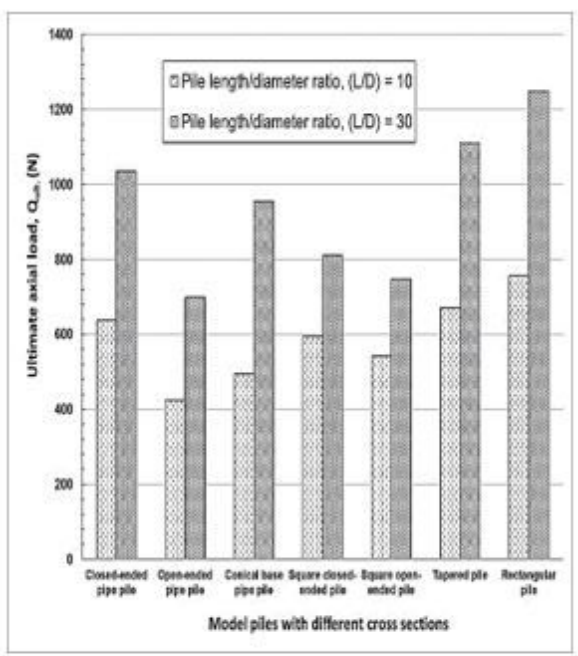

c) Dense sand, $D_{\mathrm{r}}=80 \%$

Figure 13

Values of ultimate axial load of different model piles with different pile length/diameter (L/D) ratio using jacking technique 


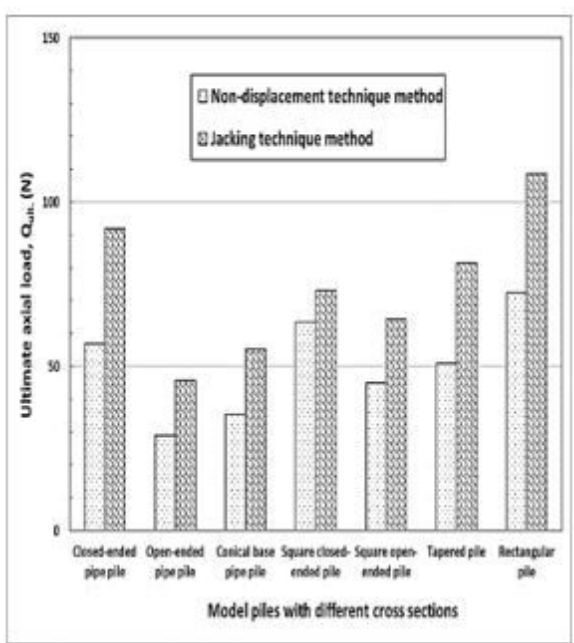

a) Loose sand, $D_{r}=33 \%$

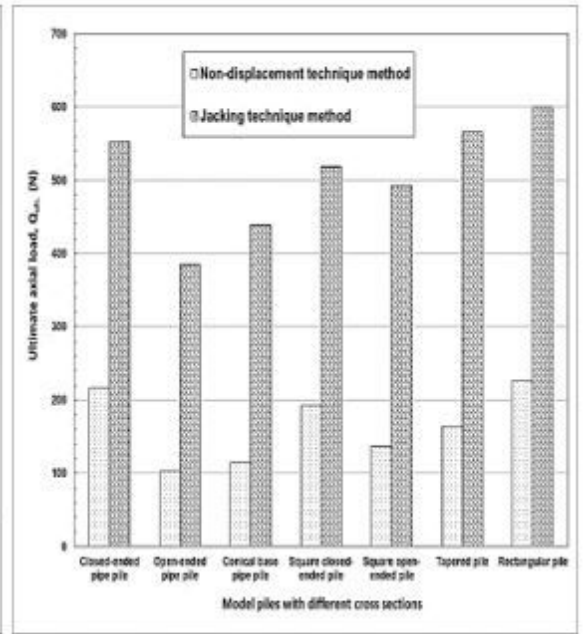

b) Medium dense sand, $D_{-}=60 \%$

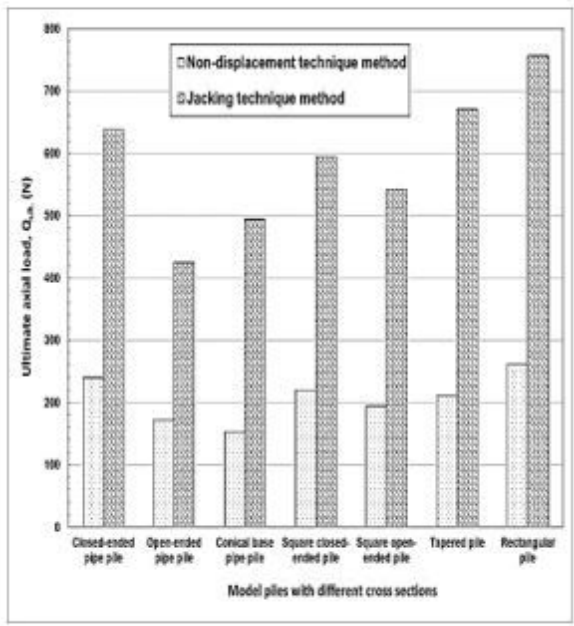

c) Dense sand, $D_{t}=80 \%$

\section{Figure 14}

Values of ultimate axial load of different model piles having pile length/diameter (L/D) ratio $=10$ with different pile installation technique methods 


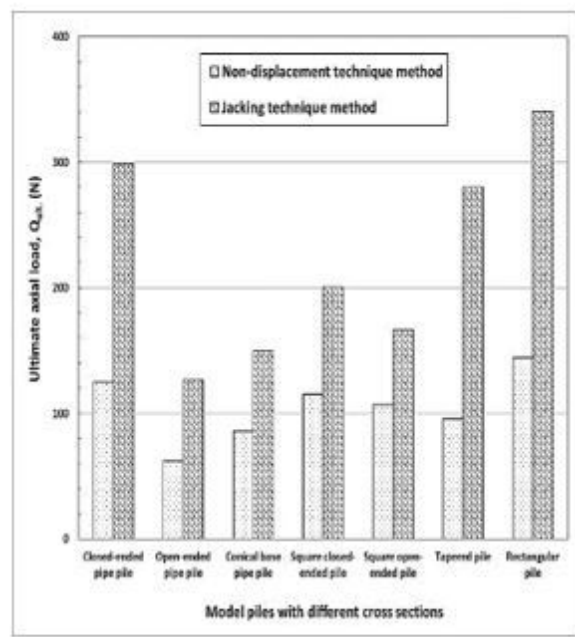

a) Loose sand, $D_{r}=33 \%$

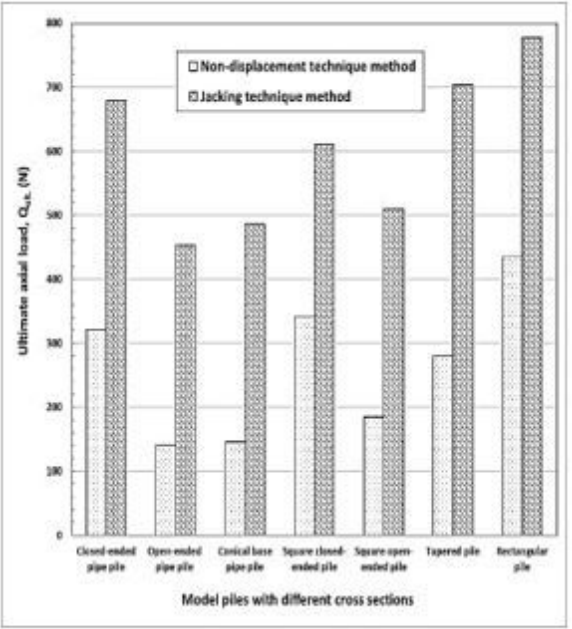

b) Medium dense sand, $\mathrm{D}_{i}=60 \%$

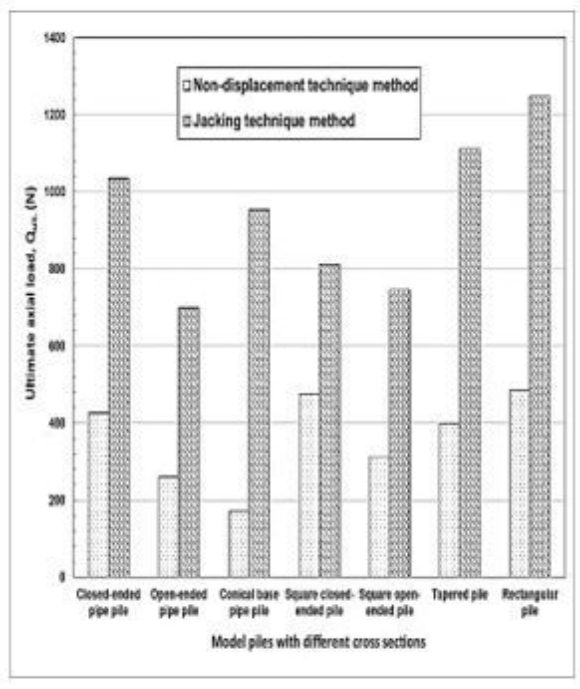

c) Dense sand, $D_{\mathrm{r}}=80 \%$

Figure 15

Values of ultimate axial load of different model piles having pile length/diameter $(\mathrm{L} / \mathrm{D})$ ratio $=30$ with different pile installation technique methods 